Structural modifications on CORM-3 lead to enhanced anti-angiogenic properties against triple-negative breast cancer cells

Authors and affiliations: Malamati Kourti ${ }^{1,2 *}$, Jun $\mathrm{Cai}^{1}$, Wen Jiang ${ }^{1}$, Andrew D. Westwell ${ }^{2}$

${ }^{1}$ Cardiff China Medical Research Collaborative, School of Medicine, Cardiff University, Heath Park, Cardiff, CF14 4XN, UK

${ }^{2}$ School of Pharmacy and Pharmaceutical Sciences, Cardiff University, Cardiff, CF10 $3 N B$, UK

*To whom correspondence should be addressed: Malamati Kourti (matinakourti@yahoo.com)

\title{
Email IDs:
}

Malamati Kourti@matinakourti@yahoo.com

Jun Cai juncai.284@gmail.com

Wen Jiang jiangw@cardiff.ac.uk

Andrew Westwell westwella@cardiff.ac.uk

Keywords: carbon-monoxide releasing molecules (CORMs), CORM-3, angiogenesis, triple-negative breast cancer (TNBC), breast cancer, anti-angiogenic therapy

Total number of Figures: 7

Total number of Tables: 3

Total number of Schemes: 2 


\section{STRUCTURED ABSTRACT}

PURPOSE: Carbon monoxide-releasing molecules (CORMs) are a special class of organometallic complexes that have been reported to offer beneficial effects against different conditions including several subtypes of cancer. Especially for the aggressive and poorly treated triple-negative breast cancer (TNBC), early CORMs have been shown to diminish malignant angiogenesis and may be considered as an alternative approach. So, this study aimed at testing novel CORM molecules against angiogenesis in TNBC seeking potent drug candidates for new therapies. METHODS: Based on previous studies, CORM- 3 was chosen as the lead compound and a group of 15 new ruthenium-based CORMs were synthesized and subsequently evaluated in vitro for potential anti-angiogenic properties. RESULTS: A similar anti-angiogenic behaviour to the lead complex was observed and a new CORM, complex 4, emerged as a promising agent from this study. Specifically, this complex offered better inhibition of the activation of VEGFR2 and other downstream proteins of vascular endothelial cells. Complex 4 also retained the ability of the parent molecule to reduce the upregulated VEGF expression from TNBC cells and inhibit endothelial cell migration and new vessel formation. The lack of significant cytotoxicity and the downregulating activity over the cytoprotective enzyme haem oxygenase-1 (HO-1) in cancer cells may also favour CORMs against this poorly treated subtype of breast cancer. CONCLUSIONS: Since the anti-angiogenic approach is one of the few available targeted strategies against TNBC, both CORM-3 and the new complex 4 should be considered for further research as combination agents with existing anti-angiogenic drugs for a more effective treatment of malignant angiogenesis in TNBC. 


\section{INTRODUCTION}

Breast cancer comprises one of the most frequent types of cancer with over 1.5 million new cases diagnosed worldwide each year leading to around 0.5 million deaths. Treatment options for the most aggressive forms of the disease remain of poor efficiency and high cost with new therapies only offering marginal improvements in long term efficacy, placing breast cancer as an urgent healthcare issue [1]. Triplenegative breast cancer (TNBC) is deprived of the immunohistochemical expression of the two important hormone receptors (HR), that is the oestrogen and progesterone receptors that could be exploited as therapeutic targets, as well as the overexpression of the HER2 gene. These cancers represent $10 \%$ to $20 \%$ of all breast cancer incidence and tend to affect minority women of young age ( $<40$ years old), have a high histological grade, an increased risk of metastasis or recurrence to distant organs and a worse prognosis than HR-positive breast cancers [2-4].

As the available single treatment options for this unique subtype of breast cancer remain poorly effective, combination approaches are prescribed instead, as they offer better results, even though still unsatisfactory and lacking long-term effectiveness [5]. The process of new capillary formation from pre-existing blood vessels that allows the tumour to secure nutrients and paths of excretion - angiogenesis - has been widely targeted especially in TNBC where therapeutic options are limited. Moreover, angiogenesis has been found overexpressed in TNBC helping the aggressiveness and metastatic ability of the primary tumour [6-8]. Vascular endothelial growth factor (VEGF) and its network of receptors, mainly VEGFR2, regulate angiogenesis and are implicated with TNBC in order to enhance aggressive phenotypes. VEGF expressed by cancer cells reaches its receptors on adjacent endothelial cells (ECs) and stimulates the pro-angiogenic pathway that will lead to the activation of these ECs and the subsequent formation of new capillary vessels. Hence, not only the interaction between VEGF-VEGFR2 but also the downstream kinases of the VEGFR2 pathway offer therapeutic targets for TNBC and might also help in overcoming the resistance correlated with it [9-11]. Nevertheless, recent advances in small molecular inhibitor and monoclonal antibody (mAb) therapies against either VEGF or its receptors have not yet managed to control this subtype of breast cancer, hence TNBC is still 
considered an unmet medical need urging new combinatorial anti-angiogenic therapies [12].

Carbon monoxide ( $\mathrm{CO}$ ) belongs to the group of gasotransmitters, along with nitric oxide and hydrogen sulphide, a role that became recognized only recently. Endogenously produced $\mathrm{CO}$ is a by-product of the catabolism of haem catalysed by enzymes called haem oxygenases (HOs), and it was found to regulate endogenous signalling pathways related to cellular metabolism, inflammation and cytoprotection $[13,14]$. Nevertheless, the application of CO as a therapeutic entity still has to overcome many obstacles linked to its inherent toxicity due to the high affinity towards haemoglobin, its low bioavailability and the poor regulation of its administration as a gas [15]. Hence, the discovery of transition metal carbonyls that can act as CO-releasing compounds (CORMs) has provided a promising strategy for delivering amounts of $\mathrm{CO}$ in vivo with the ability of tuning the area and the timing of delivery [16]. Several CORMs have been explored taking advantage of the affinity of CO for transition-metal complexes, the ability of CO ligands to be released upon triggering with light or the enzymatic activity of relevant enzymes or in a $\mathrm{pH}$ dependent manner [17-23]. Despite the potential therapeutic value of CORMs against various diseases, previous literature proves that $\mathrm{CO}$ behaves differently and even with opposite results against distinct cancer subtypes [24-26]. Interestingly, a recent study [27] showed a promising anti-angiogenic activity of first and second generation CORMs, especially CORM-2 and CORM-3. These observations correlated well with previous literature [28] and developed a new possibility for the use of these unique complexes against TNBC.

Based on the above literature, we designed and synthesized a group of novel CORMs based on CORM-3 and shed more light on their potential anti-angiogenic properties in a TNBC subset following known procedures. Novel observations that emerged from this study lead us to suggest a novel CORM, complex 4, as potent agent to be pursued further in combination with existing anti-angiogenic therapies for a more effective targeting of malignant angiogenesis in TNBC.

\section{MATERIALS AND METHODS}




\section{Chemicals, solvents and instruments for synthesis}

All chemical starting materials including tricarbonyldichlororuthenium (II) dimer $\left[\mathrm{Ru}(\mathrm{CO})_{3} \mathrm{Cl}_{2}\right]_{2} \quad$ (CORM-2), tricarbonylchloro(glycinate)-ruthenium (II) $\mathrm{Ru}(\mathrm{CO}){ }_{3} \mathrm{Cl}-$ glycinate (CORM-3) and all the anhydrous solvents were purchased from SigmaAldrich (Dorset, UK). Amino acids and their derivatives were obtained from Alfa Aesar (Lancashire, UK) and used without further purification, unless otherwise stated. Fluka silica gel (35-70mm) (Bucharest, Romania) was used as the stationary phase for column chromatography.

${ }^{1} \mathrm{H}$ NMR spectra were measured on a Bruker AVANCE 500 UltraShield NMR spectrometer $(500 \mathrm{MHz})$ at ambient temperature. Data was recorded as follows: chemical shifts in ppm from internal tetramethylsilane, multiplicity ( $s=$ singlet; $d$ =doublet; $\mathrm{t}$ =triplet; $\mathrm{m}$ =multiplet), coupling constant $(\mathrm{Hz})$, integration and assignment. ${ }^{13} \mathrm{C}$ NMR spectra were measured on a Bruker AVANCE UltraShield NMR spectrometer (125 MHz) at ambient temperature. Chemical shifts were recorded in ppm from the solvent resonance employed as the internal standard $\left(\mathrm{CDCl}_{3}\right.$ at 77.16ppm, MeOD at 49.00ppm, DMSO- $d_{6}$ at $39.52 \mathrm{ppm}$, THF- $d_{8}$ at $67.21 \mathrm{ppm}$ and 25.31ppm). Thin layer chromatography (TLC) was conducted on pre-coated silica gel $60 \mathrm{GF}_{254}$ plates. Preparative TLC plates $(20 \times 20 \mathrm{~cm}, 500-2000$ silica) were purchased from Merck (Southampton, UK). High-resolution mass spectrometry (HRMS) was performed on a Waters Synapt G2-Si MS system in ESI mode.

\section{Reagents for biological assays}

Recombinant human VEGF-A was purchased from R\&D Systems (Minneapolis, USA). We obtained the mouse anti-phospho-ERK1/2 (Y204) and anti-GAPDH from Santa Cruz Biotechnology (Heidelberg, Germany). The anti-phospho-VEGFR-2 (Y1175), antiphospho-Src (Y419) and anti-phospho-FAK (Y397) were obtained from Abcam (Cambridge, UK). The rabbit anti-HO-1 was purchased from Enzo Life Sciences (Exeter, UK). All antibodies used in the study are summarised in Table 1. Basement membrane matrix was from BD Biosciences (Oxford, UK). All other cell culture reagents were obtained from Sigma-Aldrich (Dorset, UK), unless otherwise stated.

\section{Cell culture}


MDA-MB-231 and HECV cell lines were routinely maintained in Dulbecco's Modified Eagle's medium (DMEM/Ham's F-12 with L-Glutamine) supplemented with $10 \%$ heatinactivated foetal bovine serum (FBS) and $1 \%$ of antibiotic cocktail mix. MCF-10A cells were routinely maintained in Mammary Epithelial Basal Medium (MEBM, Lonza, Gloucestershire, UK) supplemented with the recommended growth supplements (MEGM kit) (Lonza), 1\% antibiotic cocktail mix and 100ng/mL cholera toxin. HUVEC cells were routinely maintained in Endothelial Cell Growth Basal Medium-2 (EBM-2, Lonza) supplemented with the recommended growth supplements (EGM-2 BulletKit) (Lonza), 1\% antibiotic cocktail mix and 2\% FBS. All the cells were grown to confluence in $25 \mathrm{~cm}^{3}$ culture flasks loosely capped (Greiner Bio-One Ltd., Gloucestershire, UK) at $37^{\circ} \mathrm{C}$ in $5 \% \mathrm{CO}_{2}$ and $95 \%$ humidity. The flasks were left to reach adequate confluence before conducting each experiment, unless otherwise stated.

\section{Viability assay}

The MTT [(3-(4,5-dimethylthiazol-2-yl)-2,5-diphenyltetrazolium bromide] assay was conducted as reported in literature [29]. Briefly, a 96-well plate was seeded with $5 \times 10^{3}$ cells in normal medium $24 \mathrm{~h}$ before the treatment. Increasing concentrations of CORMs or vehicle were then administered for further $72 \mathrm{~h}$. Then a $5 \mathrm{mg} / \mathrm{ml} \mathrm{MTT}$ solution was added for $4 \mathrm{~h}$, the medium was aspirated, and $100 \mu \mathrm{l}$ acidified isopropanol dissolved the formed purple formazan crystals. The absorbance of the test plate was read at 540nm using an ELx800 plate reading spectrophotometer (Bio-Tek, Wolf laboratories, York, UK), subtracting any background absorbance. The absorbance of each compound concentration was subsequently normalized to the vehicle treated cells prior to plotting. Data was statistically analysed using non-linear regression (curve fit) to calculate the $\mathrm{IC}_{50}$ value in GraphPad Prism (GraphPad Prism Version 6.0, www.graphpad.com).

\section{VEGF quantification in cell culture supernatant}

An adequately confluent monolayer of MDA-MB-231 cells was treated with $100 \mu \mathrm{M}$ CORMs or $0.1 \%$ DMSO or fresh media for $6 \mathrm{~h}, 12 \mathrm{~h}$ or $24 \mathrm{~h}$. The supernatant was then collected, centrifuged to remove debris and aliquoted in $1 \mathrm{~mL}$ Eppendorf tubes that were kept in deep freezer until required. The total protein content of each culture was 
also quantified using the Bio-Rad DC Protein Assay kit (Bio-Rad laboratories, Hemel Hempstead, UK) and used to normalize the results. Each aliquot was thawed before use and the concentration of VEGF was quantified using the human VEGF ELISA kit (Life Technologies Ltd., Paisley, UK) following the manufacturer's instructions.

\section{Quantification of phosphorylated proteins in stimulated HUVEC cells}

Serum starved HUVEC cells were treated with $100 \mu \mathrm{M}$ CORMs or $0.1 \%$ DMSO or serum free media (SFM) for $15 \mathrm{~min}$. After that, $100 \mathrm{ng} / \mathrm{mL}$ VEGF was used to stimulate the cells for $5 \mathrm{~min}$. The supernatant was then discarded, and the cells lysed. The lysate was used either for ELISA or for Western blot analysis as reported previously [30], and the results were normalized to the total protein content. All the antibodies used in this study are listed in Table 1.

\section{Conditioned media preparation and Tube formation assay}

An adequately confluent monolayer of MDA-MB-231 cells was treated with $100 \mu \mathrm{M}$ CORMs or $0.1 \%$ DMSO or fresh media for $6 \mathrm{~h}, 12 \mathrm{~h}$ or $24 \mathrm{~h}$. The supernatant was then collected, centrifuged to remove debris and used to supplement HECV cells which were seeded on top of a pre-set layer of Matrigel and left to adhere. Alternatively, direct treatments of $100 \mu \mathrm{M}$ CORMs or $0.1 \%$ DMSO or SFM were administered on preseeded HECV cells on top of Matrigel. After $6 \mathrm{~h}$, the wells were imaged using a Leica DM 1000 LED microscope (Leica Microsystems, Milton Keynes, UK) capturing at least 3 images/well at random areas. The images were analysed using the ImageJ software (National Institutes of Health, NY, USA, https://imagej.nih.gov/ij/) and the percentage of total tube length compared to the vehicle was calculated from three independent experiments performed in triplicate.

\section{Traditional Scratch wound assay}

A confluent monolayer of HECV cells was washed with PBS, wounded vertically with a pipette tip, re-washed twice and treated with normal media containing $100 \mu \mathrm{M}$ CORMs or $0.1 \%$ DMSO or no treatment for $24 \mathrm{~h}$. Photos were taken at $0 \mathrm{~h}, 4 \mathrm{~h}, 8 \mathrm{~h}, 12 \mathrm{~h}$ and $24 \mathrm{~h}$ after wounding using a Leica DM 1000 LED microscope. Migration distances were measured using the ImageJ software and the percentage of open wound 
compared to vehicle was calculated from three independent experiments performed in triplicate.

\section{Quantification of HO-1 in cancer cells}

An adequately confluent monolayer of MDA-MB-231 cells was treated with $100 \mu \mathrm{M}$ CORMs or $0.1 \%$ DMSO or fresh media for $12 \mathrm{~h}$. The total protein of each culture was then quantified and subjected to Western blot analysis. Briefly, after the SDS-PAGE, the proteins were transferred onto nitrocellulose membrane which was then blocked and probed with the relevant primary and the corresponding peroxidase-conjugated secondary antibodies. The protein bands were eventually visualized using the chemilluminescence detection system EZ-ECL (Biological Industries, Cromwell, USA) and the total GAPDH protein was used as the internal loading control [30].

\section{Statistical analysis}

Statistical analysis was performed using GraphPad Prism. Unpaired Student's $t$-test with Welch's correction for two groups, non-parametric Mann-Whitney $t$-test for Western blot and two-way ANOVA for multiple groups were performed to check for statistical significance, with a p-value of $<0.05$ considered statistically significant. Asterisk notation $\left({ }^{*}\right)$ was used to identify significance: ${ }^{*} p<0.05, * * p<0.01$ and $* * *$ $p<0.001$.

\begin{tabular}{|c|c|c|c|c|}
\hline Antibody name & $\begin{array}{c}\text { Molecular } \\
\text { weight (kDa) }\end{array}$ & $\begin{array}{c}\text { Phosphorylation } \\
\text { site }\end{array}$ & $\begin{array}{c}\text { Final } \\
\text { concentration } \\
\text { used }\end{array}$ & Product code \\
\hline Mouse anti-GAPDH & 37 & - & $0.2 \mu \mathrm{g} / \mathrm{mL}$ & $\mathrm{SC}-32233$ \\
\hline Mouse anti-pERK1/2 & $42 / 44$ & $\mathrm{Y} 204$ & $0.4 \mu \mathrm{g} / \mathrm{mL}$ & $\mathrm{SC}-7383$ \\
\hline Rabbit anti-pVEGFR2 & 152 & $\mathrm{Y} 1175$ & $1.49 \mu \mathrm{g} / \mathrm{mL}$ & $\mathrm{Ab}-194806$ \\
\hline Rabbit anti-pSrc & 60 & $\mathrm{Y} 419$ & $0.538 \mu \mathrm{g} / \mathrm{mL}$ & $\mathrm{Ab}-185617$ \\
\hline Rabbit anti-HO-1 & 32 & - & $1.0 \mu \mathrm{g} / \mathrm{mL}$ & $\mathrm{HC} 3001$ \\
\hline Rabbit anti-pFAK & 119 & $\mathrm{Y} 397$ & $1.0 \mu \mathrm{g} / \mathrm{mL}$ & $\mathrm{Ab}-81298$ \\
\hline
\end{tabular}

Table 1 Antibodies used in the study

\section{RESULTS}

\section{Design and synthesis of the new complexes}


The well-defined literature complex CORM-3 was selected as the parent compound for the design and synthesis of a small series of new analogues. CORM-2 $\left[\mathrm{Ru}(\mathrm{CO})_{3} \mathrm{Cl}_{2}\right]_{2}$ was used by all relevant publications as the starting material for the synthesis of CORM-3, as depicted in Scheme 1 [18]. Glycine binds each Ru core of CORM-2 through the amine and the carboxylic groups, forming two identical mononuclear adducts with only one remaining $\mathrm{Cl}$ atom. In general, amino acids are first-choice ligands, because they are well-characterized and can be obtained in high chemical purity, thus comprise ideal starting materials. They also react with many transition metals and may increase the water solubility of the formed metal complex [31]. Therefore, the design idea was to replace the glycine moiety of CORM-3 with other amino acids, most of them more lipophilic than glycine. Given the zwitterionic character of amino acids, the overall hydrophilicity of these molecules should remain very high (negative clogP values) but an increase in their lipophilicity could enable these molecules to cross cellular membranes by passive diffusion routes (as opposed to active transporter uptake for very hydrophilic molecules). This strategy was designed to provide more experimental/ proof-of-concept agents, but in order to make a druggable compound of course a fine balance between hydrophilicity and lipophilicity should be carefully considered at a later stage.

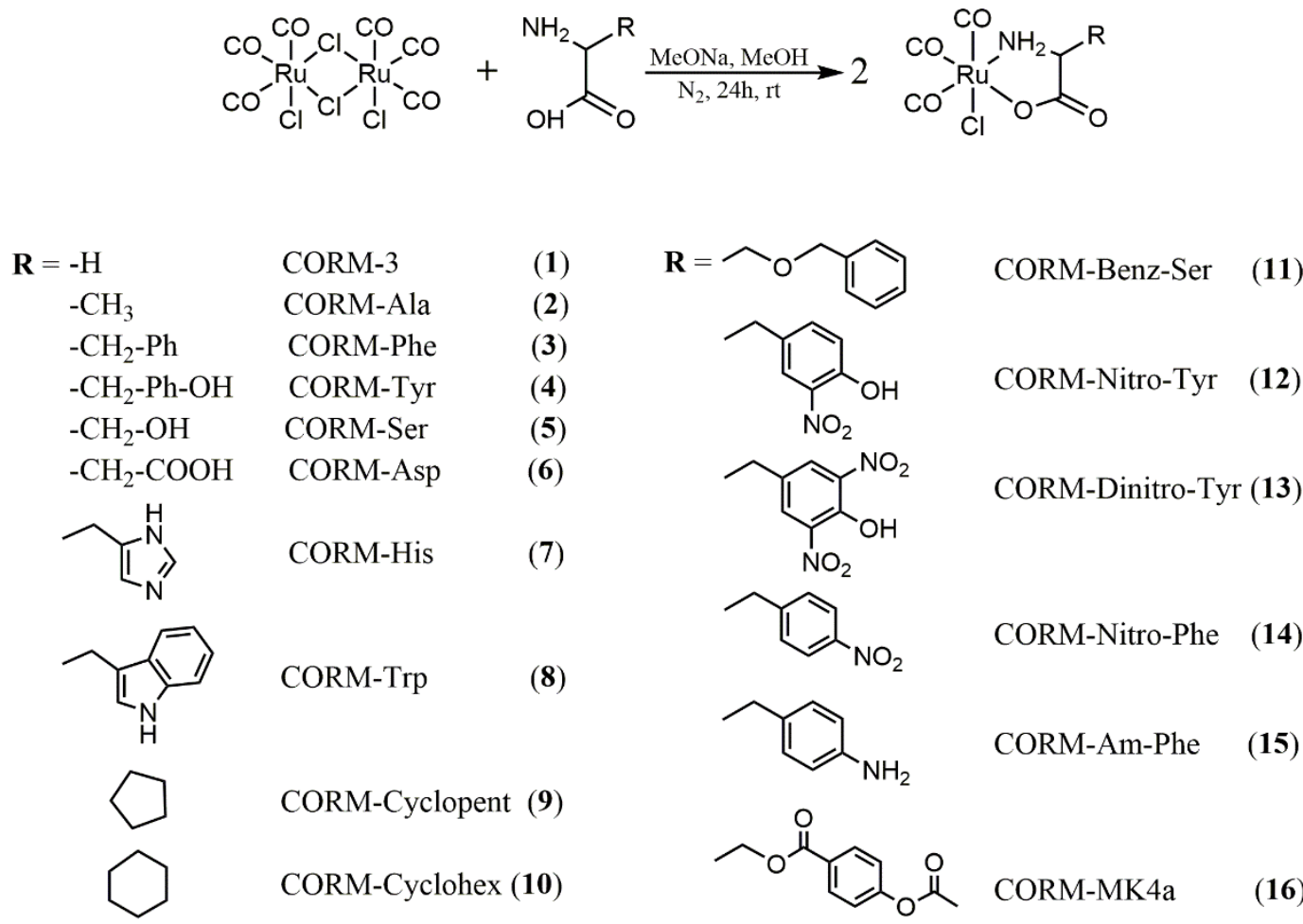


Scheme 1 Synthesis. Synthetic scheme for CORM-3 analogues and synthesized complexes

Eight of the 20 natural standard amino acids were chosen, and the relevant derivatives were synthesized (amino acids and properties shown in Table 2). The other approach was based on the substitution of glycine with uncommon amino acids, such as $\alpha, \alpha$ dialkylated amino acids and derivatives of tyrosine, phenylalanine and serine with common groups. The $\alpha, \alpha$-dialkylated amino acids with the alicyclic ring and the quaternary $\alpha$-carbon atom pose conformational constraints to the whole complex, thereby stabilizing a pre-set conformation that may help in creating a packed complex structure. This way, these complexes might be characterized by higher lipophilicity but similar polar surface area to CORM-3. Aminocyclopentane carboxylic acid (ACPC) has been previously well studied and shown to have a selective uptake by tumour tissue and react with amino acid transport systems $A$ and $L$, as well as inhibit a variety of carcinomas, such as Walker carcinoma 256 and adenocarcinoma 755 [32,33]. Aminocyclohexane carboxylic acid (ACHC) is symmetric and achiral, so no optically active compounds are formed, and the cyclohexane ring contributes to the total lipophilicity of the final molecule, potentially affecting its efficacy. Various derivatives of $\mathrm{ACHC}$ have been approved by the FDA as pharmacologically relevant compounds (Cyclacillin, Spiromustine, Balicatib) [34]. Other phenylalanine, tyrosine and serine derivatives with common groups were also used as substituents. The nitro group was chosen due to its innate toxicity linked also to ROS production. In particular, 4-nitrophenylalanine and 3-nitro-tyrosine were previously found to inhibit amino acid activation and the transfer of phenylalanine into microsomes during protein synthesis, leading to toxicity against HT-29 colorectal adenocarcinoma cells. Promotion of DNA degradation was also observed $[35,36]$. The last chosen ligand was formed by the conjugation of 4-acetoxybenzoic acid with serine, in order to enhance the pro-oxidant activity of the final complex, based on the research done by the group of Simić et al. [37], where p-hydroxy-benzoic acid was shown to have a pro-oxidant moiety. The acetyl-protection was used as an extra measure against fast metabolism and to moderate the high polarity imparted by a free hydroxyl group.

The syntheses of carbonyl ruthenium complexes 1-16 commenced from the commercially available reagent CORM-2 $\left[\mathrm{Ru}(\mathrm{CO})_{3} \mathrm{Cl}_{2}\right]_{2}$ which reacted with amino acids 
or their derivatives to generate the product complexes (Scheme 1). All ruthenium complexes were obtained in moderate to good yields. They are powder solids from off-white to yellow and stable if exposed to air but moderately unstable if exposed to light, apart from complex 5, which appeared to be oxidized under these conditions and turn into a waxy dark yellow solid. Only complexes $\mathbf{1}$ and $\mathbf{7}$ dissolve easily in water opposing other literature about complex 2 [38]. All other ruthenium complexes have poor water solubility, and all can dissolve in organic solvents such as DMSO, complexes 12, 13 and 15 also in methanol, and complexes 1, 2, 8, 11 and 16 also in tetrahydrofuran (THF). All synthesized complexes were characterized by standard methods of NMR spectroscopy and high-resolution mass spectrometry (HRMS) (see Experimental Section).

For complex 16 the ligand had to be prepared separately before the final conjugation with CORM-2, so N-benzyloxycarbonyl-L-serine benzyl ester was conjugated with 4acetoxybenzoic acid and then subjected to hydrogenolysis to remove the benzyloxy protecting group.

The hydrophilicity of a molecule can be measured by its clogP (computational logP) and TPSA (topological polar surface area) values. The partition coefficient of a molecule $(\log \mathrm{P})$ can affect target accessibility and binding, as well as the duration for full metabolism. ClogP determines the pharmacokinetics and pharmacodynamics of a molecule, namely its ADMET properties and target receptor engagement. The predicted toxicity of a molecule may also depend on lipophilicity, since lipophilic molecules tend to have an extended retention in the body, have a wider and uncontrolled tissue distribution, bind to blood proteins and receive a broad metabolism [39]. Therefore, $\log P$ (or clogP) potentially determines the druggability of a molecule intended for oral administration [40-42]. The topological polar surface area (tPSA) of a molecule is calculated adding its polar atoms' surfaces, mainly from oxygen and nitrogen and attached hydrogens. Medicinal chemists tend to replace the "molecular mass less than 500 Daltons" rule of Lipinski's rule of five with the tPSA value, in order to predict potential cell membrane permeability for a pharmacologically relevant molecule [43]. 
In summary, the amino acids chosen to replace glycine in CORM-3 are depicted in Table 2, along with their chemical properties and the properties of the final synthesized complexes.

\begin{tabular}{|c|c|c|c|c|c|}
\hline Ligand & cLogP & tPSA & Complex & cLogP & tPSA \\
\hline Glycine & -3.21 & 63.32 & CORM-3 (1) & -2.318 & 94.61 \\
\hline Alanine & -3.124 & 63.32 & CORM-Ala (2) & -1.799 & 94.61 \\
\hline Phenylalanine & -1.556 & 63.32 & CORM-Phe (3) & -0.381 & 94.61 \\
\hline Tyrosine & -2.223 & 83.55 & CORM-Tyr (4) & -1.048 & 114.84 \\
\hline Serine & -2.811 & 83.55 & CORM-Ser (5) & -2.768 & 97.77 \\
\hline Aspartic acid & -2.412 & 100.62 & CORM-Asp (6) & -2.329 & 131.91 \\
\hline Histidine & -3.727 & 87.71 & CORM-His (7) & -2.782 & 119.00 \\
\hline Tryptophan & -1.566 & 75.35 & CORM-Trp (8) & -0.391 & 106.64 \\
\hline $\begin{array}{c}\text { 1-Aminocyclopentane- } \\
\text { carboxylic acid }\end{array}$ & -2.254 & 63.32 & CORM-Cyclopen (9) & -0.886 & 94.61 \\
\hline 1-Aminocyclohexane- \\
carboxylic acid & -1.695 & 63.32 & CORM-Cyclohex (10) & -0.327 & 94.61 \\
\hline O-Benzyl-Serine & -0.819 & 72.55 & CORM-Benz-Ser (11) & -0.259 & 103.84 \\
\hline 3-Nitro-Tyrosine & -1.844 & 135.36 & CORM-Nitro-Tyr (12) & -1.305 & 166.65 \\
\hline 3,5-Dinitro-Tyrosine & -1.878 & 187.17 & CORM-Dinitro-Tyr (13) & -1.562 & 218.46 \\
\hline 4-Nitro-Phenylalanine & -1.813 & 115.13 & CORM-Nitro-Phe (14) & -0.638 & 146.42 \\
\hline 4-Amino-Phenylalanine & -2.887 & 87.12 & CORM-Am-Phe (15) & -1.71 & 120.63 \\
\hline O-(4-Acetoxybenzoyl)-Serine & -1.173 & 115.92 & CORM-MK4a (16) & -0.792 & 147.21 \\
\hline
\end{tabular}

Table 2 Amino acids as ligands of the new CORMs and the final synthesized complexes with their chemical properties as calculated in ChemDraw Professional 16.0

\section{CORMs express low toxicity}

Molecules containing heavy metals still face prejudice among health scientists since they may prove toxic against both the environment and living organisms. Such molecules are also the organometallic compounds bound to heavy metals, although it should be kept in mind that more important characteristics of the complex might be responsible for the toxicity, that is the counter-ion present, the oxidation state, the group of ligands and not the heavy metal per se [44]. Organometallic complexes that 
release CO may present additional concerns linked to the inherent toxicity of $\mathrm{CO}$ that should not be ignored.

For this reason, MDA-MB-231 TNBC cells, MCF-10A breast epithelial cells and HECV immortalized ECs were treated with CORMs for $72 \mathrm{~h}$ and their viability subsequently tested via the MTT colorimetric assay. The new compounds proved not majorly cytotoxic against the TNBC cells compared to the DMSO vehicle. All calculated $I C_{50}$ values exceeded $100 \mu \mathrm{M}$, except for complex 9 , which had an $\mathrm{IC}_{50}$ at $89 \mu \mathrm{M}$. However, many values were very close to $100 \mu \mathrm{M}$, that is for complexes $\mathbf{2}, \mathbf{7}, \mathbf{1 2}, 13$ and 16 . Therefore, these compounds, along with complexes 3, 4, 10 and 15 were chosen to be tested against MCF-10A and HECV endothelial cells.

MCF-10A breast epithelial cells represent the control cells in a normal breast environment. Almost all the newly synthesized CORMs tested had IC $C_{50}$ values of more than $200 \mu \mathrm{M}$, although complexes $\mathbf{9 , 1 2}$ and $\mathbf{1 3}$ appeared to be more cytotoxic than the others (IC 50 of $71 \mu \mathrm{M}, 107 \mu \mathrm{M}$ and $156 \mu \mathrm{M}$, respectively). For complex 7 an $\mathrm{IC}_{50}$ could not be determined. Following up, HECV cells were checked for cytotoxicity representing normal ECs, and all novel CORMs showed very low toxicity. Table 3 shows the calculated $\mathrm{IC}_{50}$ values for all the compounds and cell lines tested. CORM-3 data was included for comparison reasons based on previous findings [27].

\begin{tabular}{|c|c|c|c|}
\hline $\mathbf{I C}_{\text {50 }}(\boldsymbol{\mu M})$ & MDA-MB-231 & MCF-10A & HECV \\
\hline Complex 1 & 312.5 & Not converged & 996.3 \\
\hline Complex 2 & 198.8 & 787.4 & 4866 \\
\hline Complex 3 & 325.3 & 340.7 & 1857 \\
\hline Complex 4 & 320.5 & 373.3 & 1681 \\
\hline Complex 5 & 1429 & n.d. & n.d. \\
\hline Complex 6 & 353.4 & n.d. & n.d. \\
\hline Complex 7 & 162.1 & Not converged & 1340 \\
\hline Complex 8 & 448.9 & n.d. & n.d. \\
\hline Complex 9 & 89.07 & 71.14 & 530.5 \\
\hline Complex 10 & 460.9 & 219.7 & n.d. \\
\hline Complex 11 & 376.4 & n.d. & n.d. \\
\hline Complex 12 & 151.8 & 106.6 & 892.8 \\
\hline Complex 13 & 171 & 156 & 1031 \\
\hline
\end{tabular}




\begin{tabular}{|c|c|c|c|}
\hline Complex 14 & 273.4 & n.d. & n.d. \\
\hline Complex 15 & 278.7 & 339.5 & 1642 \\
\hline Complex 16 & 232.9 & 698.2 & 700.3 \\
\hline
\end{tabular}

Table 3 Cytotoxicity of novel CORMs. Mean IC 50 values $(\mu \mathrm{M})$ for all compounds and cell lines tested (calculated in GraphPad Prism) ( $n=3, N=3, n . d .=$ not determined)

\section{CORMs reduce the expression of VEGF by MDA-MB-231 cells}

Malignant angiogenesis depends on the tumour's ability to excrete abundant quantities of growth factors including VEGF provoking pro-angiogenic signalling to the surrounding ECS. Subsequently the ECs around the tumour area, with an effective expression of VEGFRs (RTKs), bind the excreted VEGF and initiate these signals mainly through the activation of the VEGFR2 downstream signalling pathways. Several kinases become phosphorylated in response, regulating important functions of ECs, namely their survival, growth, migration ability and vessel formation activity. Ideally, a potent anti-angiogenic agent that can disrupt any step of the angiogenic process, that is the expression of stimulants by cancer cells or the successful vessel formation due to the signal transduction in ECs, could be used against TNBC $[10,45]$. In this study, newly synthesized CORMs were subjected to appropriate experiments for VEGF expression and VEGFR2 pathway activation. Given previous results indicating that CORM-3 seems not to regulate VEGF at the genomic level [28], these molecules were chosen not to be tested in qPCR for the purposes of this study.

The new CORMs were used to treat MDA-MB-231 cells and the concentration of excreted VEGF in the extracellular space was quantified using a human VEGF ELISA kit. As depicted in Figure 1 all novel CORMs could reduce the excreted VEGF from TNBC cells in the three time points tested. In each graph, the three novel CORMs that reduced VEGF by the highest percentage compared to the corresponding control group were highlighted in red boxes. In the 6 h treatment (Figure 1A), complexes 2, 4 and 14 reduced VEGF expression by more than 50\% each, reaching high statistical significance. Meanwhile at a lower level, complexes 6, 7 and 16 also managed to reduce VEGF with a higher statistical significance compared to the three above. The reduction in the expression of VEGF in MDA-MB-231 cells was also observed in the longer time treatments. As depicted in Figure 1B, in the $12 \mathrm{~h}$ treatment, again all 
CORMs decreased the levels of VEGF expressed, although for most of the treatments this did not reach statistical significance. The three best new CORMs in this subset were complexes 3, 11 and $\mathbf{1 2}$, which reduced VEGF by almost $50 \%$ with statistical significance reached only for complex 11. However, other CORMs such as complexes 2 and $\mathbf{6}$ showed similar reduction levels but more significant differences compared to the above ones. Finally, in the $24 \mathrm{~h}$ treatment (Figure 1C), CORMs showed higher reduction rates, with the best ones, complexes $\mathbf{3}, \mathbf{4}$ and $\mathbf{7}$, reducing VEGF expression by $50 \%, 60 \%$ and $55 \%$, respectively. The other new CORMs did not induce such a reduction or reach any higher statistical significance than the ones highlighted. 
A.

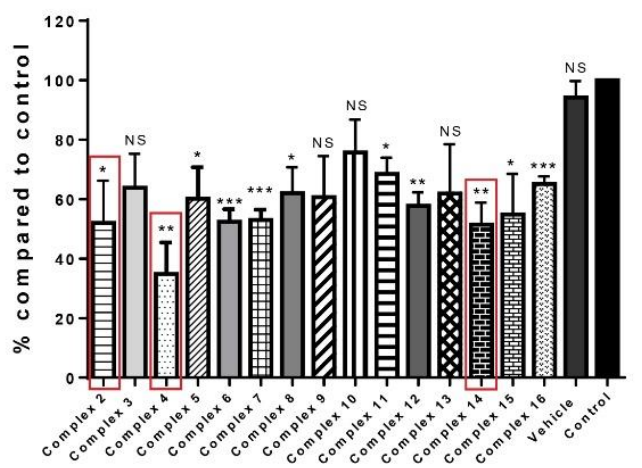

B.

VEGF expression

$12 \mathrm{~h}$

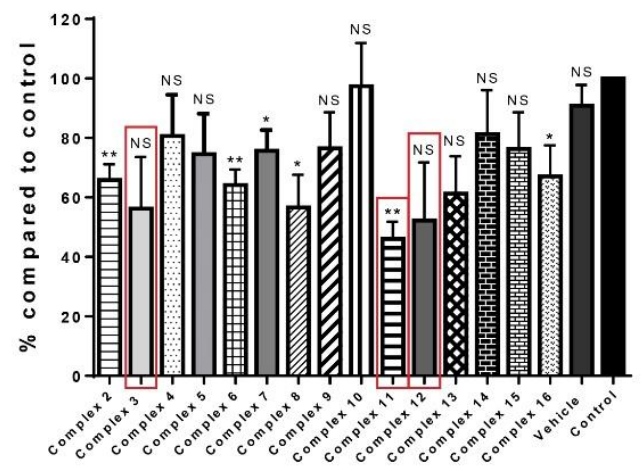

c. VEGF expression $24 \mathrm{~h}$

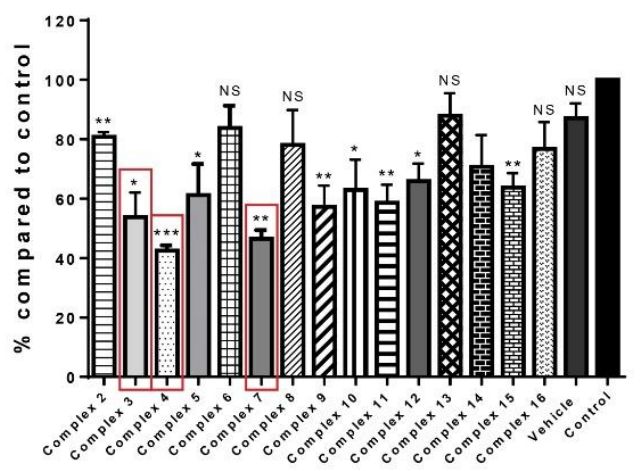

Figure 1 VEGF expression after CORM treatments. A. VEGF expression quantification in MDA-MB231 cells $6 \mathrm{~h}$ after treatment with $100 \mu \mathrm{M}$ CORMs, $0.1 \%$ DMSO or normal media, using a human VEGF ELISA kit. B. VEGF expression quantification in MDA-MB-231 cells $12 \mathrm{~h}$ after treatment with $100 \mu \mathrm{M}$ CORMs, $0.1 \%$ DMSO or normal media, using a human VEGF ELISA kit. C. VEGF expression quantification in MDA-MB-231 cells $24 \mathrm{~h}$ after treatment with $100 \mu \mathrm{M}$ CORMs, 
0.1\% DMSO or normal media, using a human VEGF ELISA kit. (All data is presented as \% compared to control +SEM; $n=3, N=3$ ). All data was statistically analysed against the corresponding duration normal media treated MDA-MB-231 cells (control) using un-paired $t$-test with Welch's correction: ${ }^{*} \mathrm{p}<0.05,{ }^{*} \mathrm{p}<0.01, * * * \mathrm{p}<0.001$. In each time point, the three new CORMs that reduce VEGF expression the most are highlighted in red boxes

\section{Complexes 3 and 4 diminish the phosphorylation of VEGFR2 downstream proteins in VEGF-stimulated endothelial cells}

The most important interaction for a successful pro-angiogenic signal happens between VEGF and VEGFR2. The binding of VEGF to VEGFR2 on the surrounding EC surface leads to the auto-dimerization of the receptor and the initiation of a downstream signal in the EC through consecutive activation of downstream proteins such as ERK, Src and FAK in later steps [46].

Given that a successful tubule formation by activated ECs prerequisites an efficient downstream transfer of the signal within the EC, the two most potent new CORMs in the previous experiment in reducing VEGF expression from TNBC cells were considered further. The ability of complexes 3 and $\mathbf{4}(100 \mu \mathrm{M})$ to inhibit the activation of four of these kinases in primary vascular ECS (HUVEC) upon VEGF stimulation was therefore studied. VEGFR2 has many phosphorylation sites, but Y1175 was selected. The phosphorylated levels of Y1175 in VEGF-stimulated ECs were quantified via an ELISA test upon CORM or vehicle pre-treatment. As shown in Figure 2A, complex 4 managed to decrease the phosphorylation closer to the levels of the unstimulated control (control) with statistical significance. This reduction was also confirmed by a Western blot analysis (Figure 2B). Complex $\mathbf{3}$ failed to decrease these levels which was evident in both the ELISA and Western blot analyses.

Selected downstream VEGF pathway proteins were also tested in a Western blot analysis. As shown in Figures $\mathbf{3 A}$ and $\mathbf{3 B}$, both ERK1 and ERK2 returned to baseline phosphorylation levels upon complexes $\mathbf{3}$ and $\mathbf{4}$ pre-treatment $(100 \mu \mathrm{M})$ with high statistical significance. Similarly, the phosphorylation of SrC at Y419 was reduced by the two new CORMs, although the protocol failed to activate Src immensely, which led to no calculated significance (Figure 3B). Finally, a similar downregulation trend was also observed for the FAK protein in Y397 for both complexes (Figure 3B). 
A.

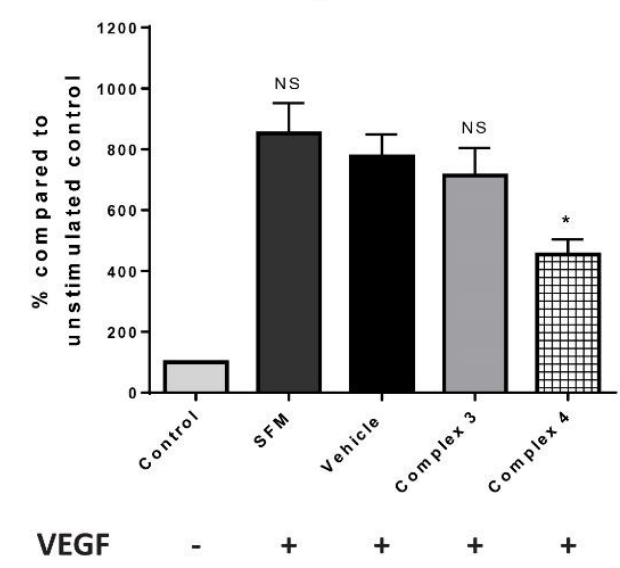

B.

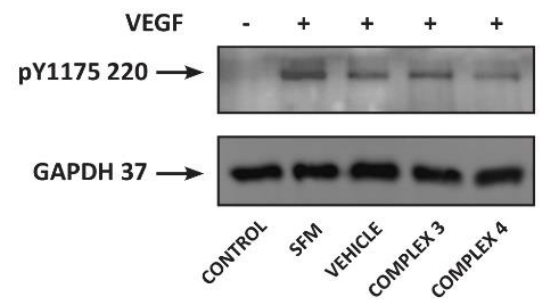

Figure 2 Quantification of pY1175 levels in HUVEC after CORM pre-treatments and VEGF stimulation. A. Expression levels of pY1175 of VEGFR2 in HUVEC after 15min of $100 \mu \mathrm{M}$ CORM or vehicle pre-incubation and then stimulation with VEGF $(100 \mathrm{ng} / \mathrm{ml})$ for $5 \mathrm{~min}$, as measured with the human pY1175-VEGFR2 ELISA kit. The first sample is the unstimulated control (control) and the second is the stimulated control (SFM=serum free media). Graph shows \% compared to control +SEM; N=3. Data statistically analysed using unpaired Student's $t$-test with Welch's correction * $p<0.05$. B. Western blot of pY1175 of VEGFR2 following the same protocol, which verifies the results of the ELISA (blots show representative data; $\mathrm{N}=3$ ) 
A.

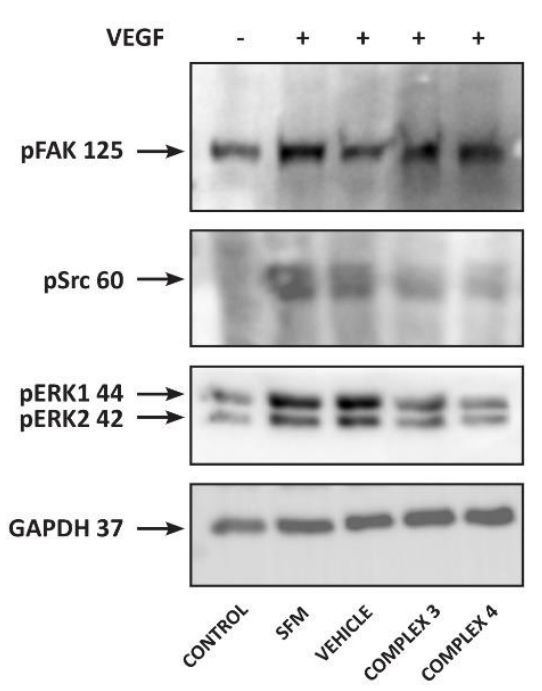

B.
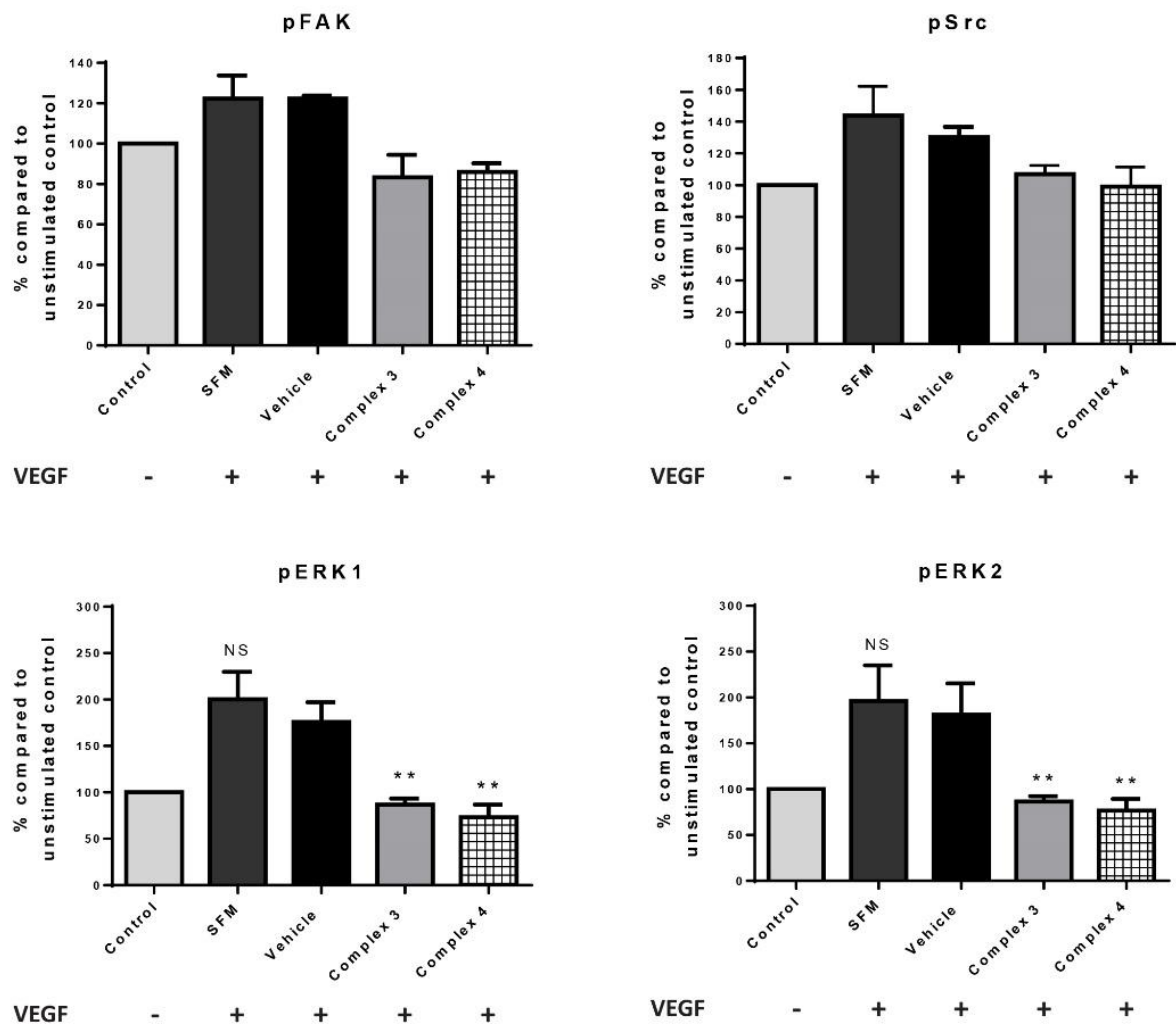

Figure 3 Expression of VEGFR2 pathway proteins in HUVEC after CORM pre-treatments and VEGF

stimulation. A. Western blot of pFAK, pSrc and pERK1/2 following 100 $\mu \mathrm{M}$ CORM or vehicle preincubation and then stimulation with VEGF for $5 \mathrm{~min}$. The first sample is the unstimulated control (control) and the second is the stimulated control (SFM) (blots show representative data; $\mathrm{N}=4$ ). $\mathrm{B}$. Assessment of pFAK, pSrc and pERK1/2 levels in HUVEC. Graphs show \% compared to control +SEM; 
$\mathrm{N}=4$. Data statistically analysed using nonparametric (Mann-Whitney) $t$-test with $* \mathrm{p}<0.05, * *$ $\mathrm{p}<0.01$

\section{Lower tube formation by endothelial cells in response to reduced VEGF stimulation from TNBC cells}

As previously discussed in this study, tumour growth depends on the interaction between VEGF and VEGFR2 which leads to pathological angiogenesis. The ability of cancer cells to activate the surrounding ECs with the expression of high levels of VEGF is decisive for new vessel formation. Thus, we speculated that the reduced VEGF expression in TNBC cells mediated by CORMs might lead to an altered tube formation ability of ECs. As these compounds were not found to be cytotoxic against ECs (Table 3), any effect observed should be a consequence of the lower concentration of VEGF expressed and excreted by the cancer cells. HECV immortalized ECs with high angiogenic capability were stimulated with conditioned media from CORM-treated MDA-MB-231 cells and the total tube length quantified thereafter.

As shown in Figures 4A and 4B, conditioned media from both complexes was found to reduce the formation of tubes by ECs by $15-40 \%$, with the conditioned media from $6 \mathrm{~h}$ cancer treatment with complex 4 being the most effective, reaching a $40 \%$ reduction. In the $12 \mathrm{~h}$ treatment the two complexes offered similar results of $10 \%$ decrease, and in the $24 \mathrm{~h}$ treatment again complex 4 exceeded the other molecule both reaching high significance. 


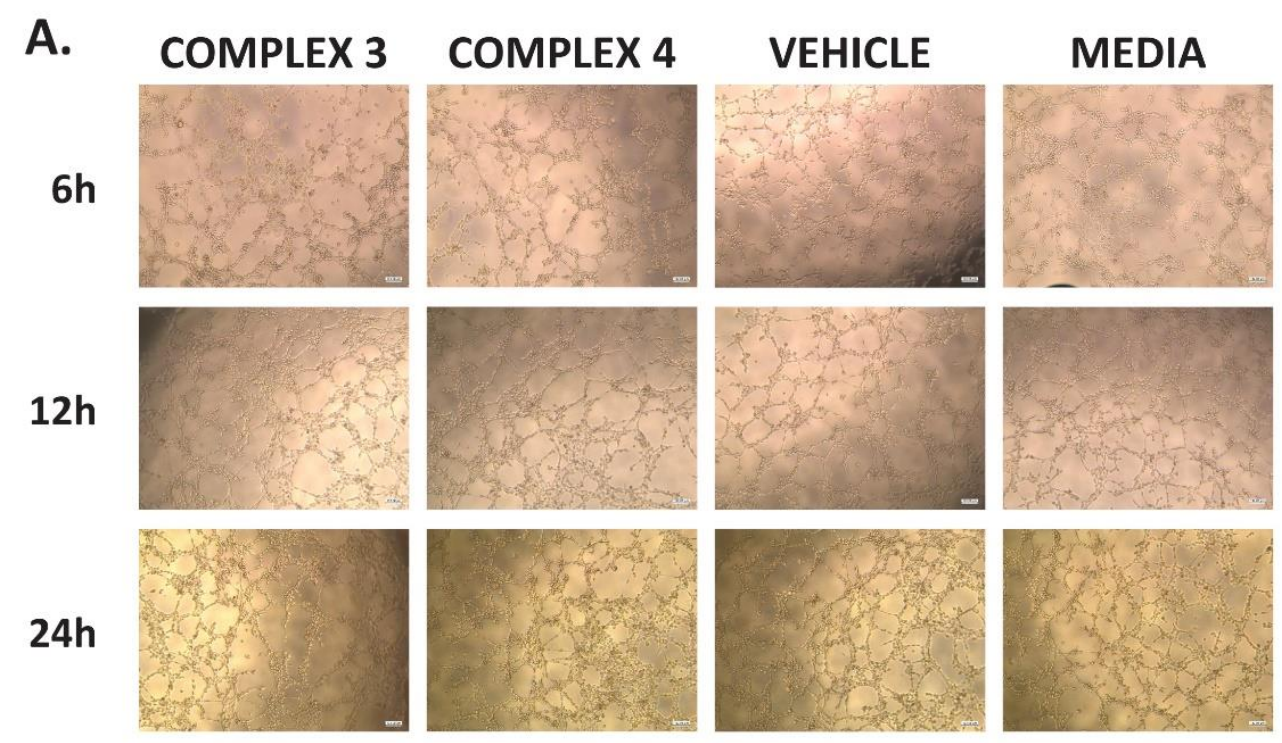

B. Tube formation

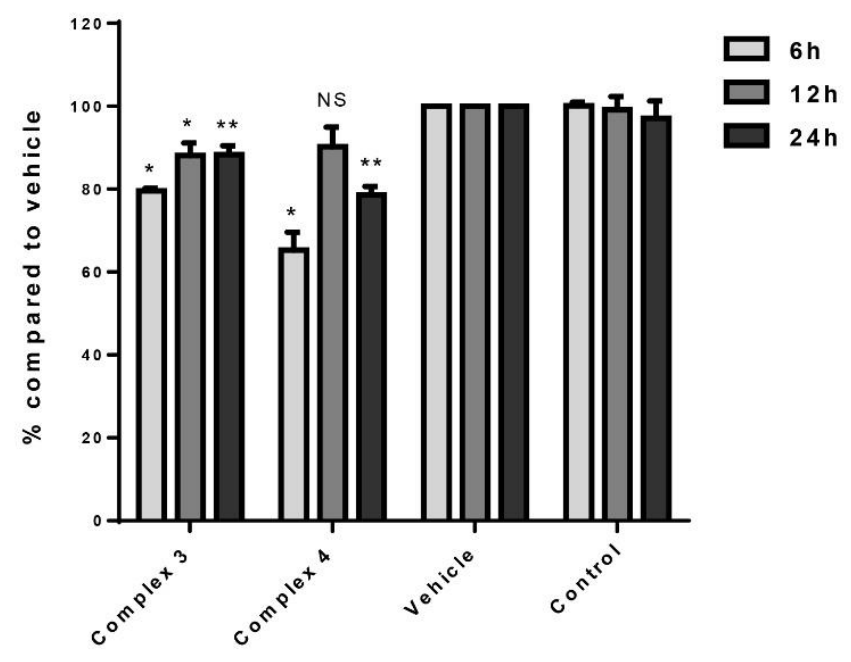

Figure 4 Tube formation ability of HECV after cancer conditioned media treatments. A. Representative images from tube formation assay with HECV cells treated with conditioned media from variable duration incubation of MDA-MB-231 cells with $100 \mu \mathrm{M}$ CORMs or $0.1 \%$ DMSO or normal media. Objective $5 x$, Scale bar $=132.08 \mu \mathrm{m}$. B. Assessment of tube formation capacity of HECV cells after conditioned media treatments. Graph shows \% total tube perimeter compared to vehicle $+S E M ; n=3, N=3$. All data was statistically analysed against the conditioned media from corresponding duration vehicle treated MDA-MB-231 cells using un-paired $t$-test with Welch's correction: $* \mathrm{p}<0.05, * * \mathrm{p}<0.01, * * * \mathrm{p}<0.001$

\section{New vessel formation is not directly affected by CORMs}


To investigate if the effect of CORMs on the tube formation ability of ECs was direct or mostly dependant on the lower VEGF stimulation, a direct treatment of CORMs was administered on HECV and $6 \mathrm{~h}$ after the treatment the total tube length was quantified in corresponding images. As shown in Figures $\mathbf{5 A}$ and $\mathbf{5 B}$ these two complexes failed to produce a significant inhibition.

A.
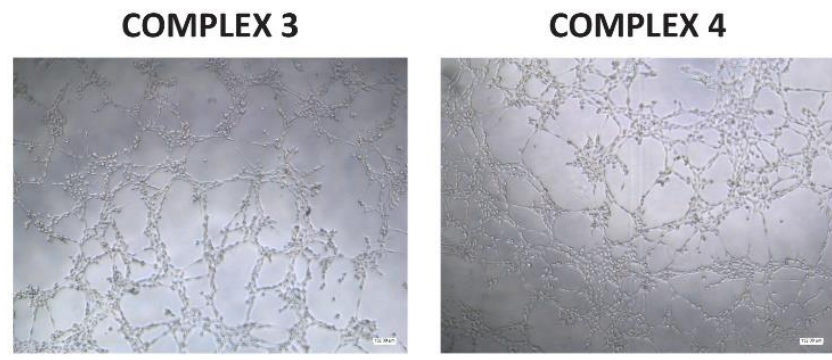

VEHICLE

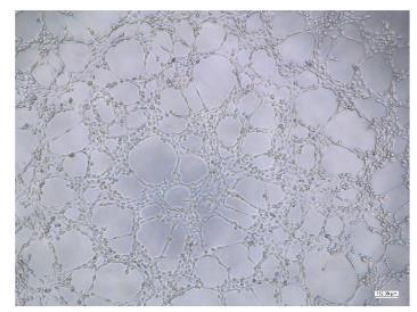

MEDIA

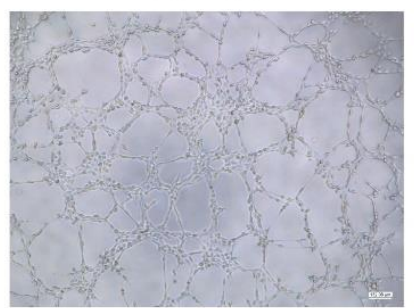

B.

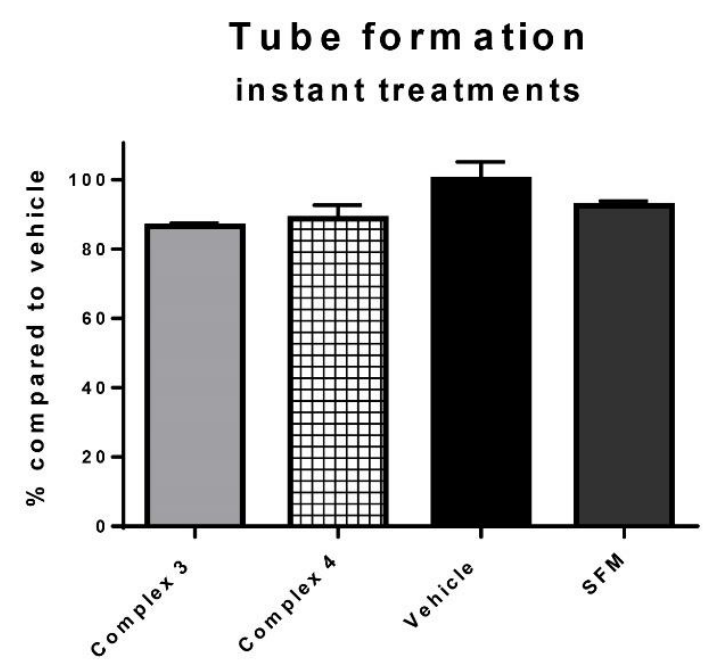

Figure 5 Tube formation ability of HECV after CORM treatments. A. Representative images from tube formation assay with HECV cells treated with $100 \mu \mathrm{M}$ CORMs or $0.1 \%$ DMSO or SFM. Objective $5 \mathrm{x}$, Scale bar $=132.08 \mu \mathrm{m}$. B. Assessment of tube formation capacity of HECV cells after instant CORM treatments. Graph shows \% total tube perimeter compared to vehicle +SEM; $n=3, N=3$. All 
data was statistically analysed against vehicle treated cells using un-paired $t$-test with Welch's

correction: * $\mathrm{p}<0.05$

Decelerated endothelial cell migration in response to complexes 3 and 4 treatments

Angiogenesis directly depends on the capability of ECs to proliferate and very importantly to migrate towards the angiogenic stimulus in response to growth factor excretion. The fine balance between the pro- and anti-angiogenic factors in a cancerous environment ultimately determines the creation of new blood vessels. The ECs need to migrate long distances in order to establish new connections [47]. Finding disruptive agents for the migration of ECs would be a promising target towards the inhibition of malignant angiogenesis.

For these reasons, the two new CORMs were investigated for any disruption in the migration of ECs following the traditional scratch wound experiment. The results can be seen in Figure 6A. As observed, complexes $\mathbf{3}$ and $\mathbf{4}$ delayed the migration of ECs, leaving a $30-50 \%$ of the induced wound still open even $24 \mathrm{~h}$ after the scratch, reaching significance (Figure 6C). 


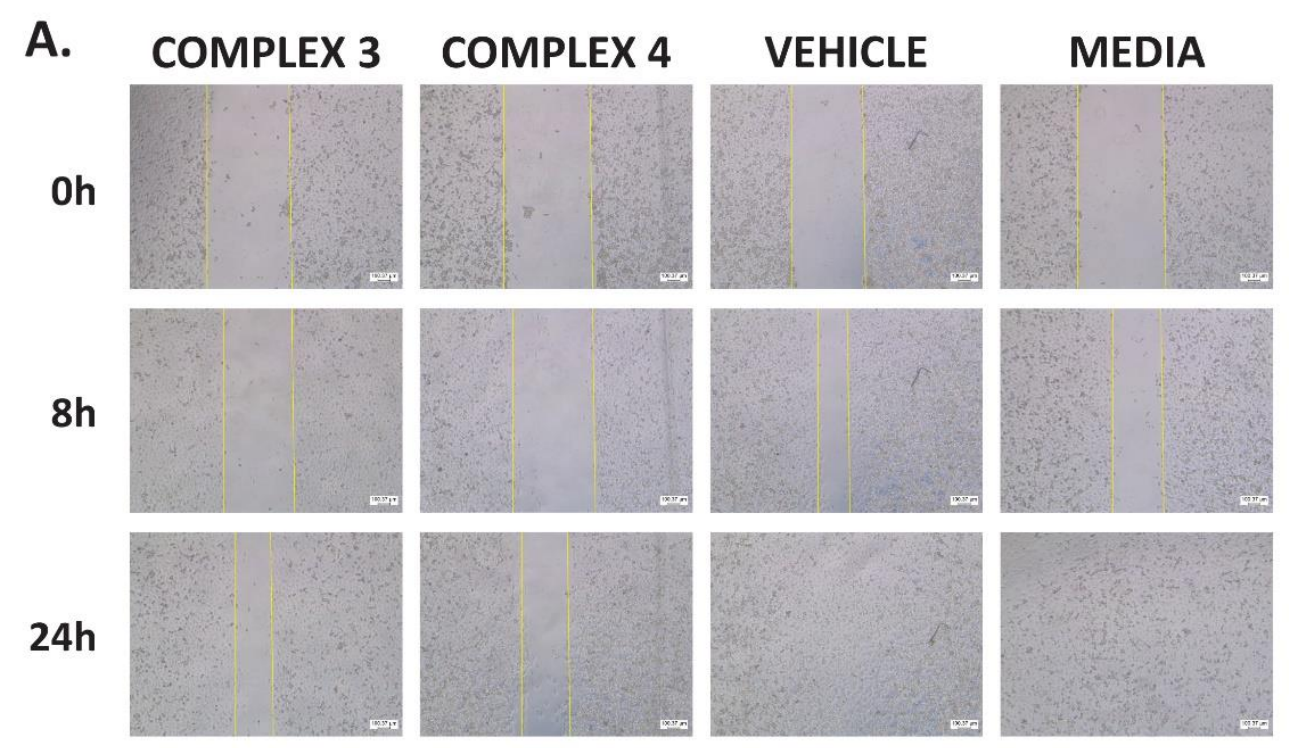

B.

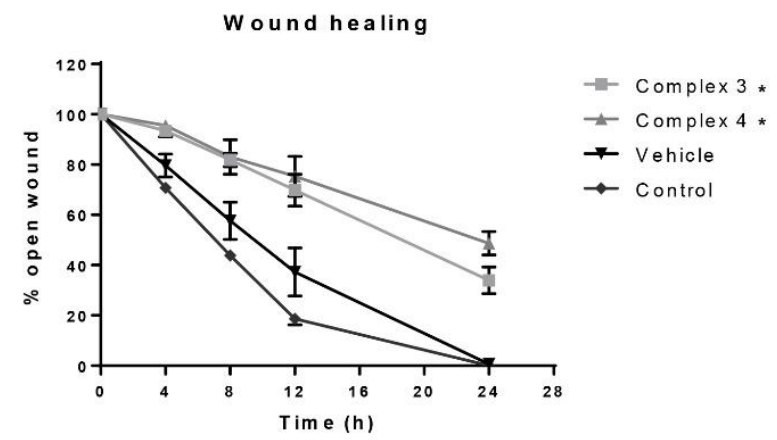

C.

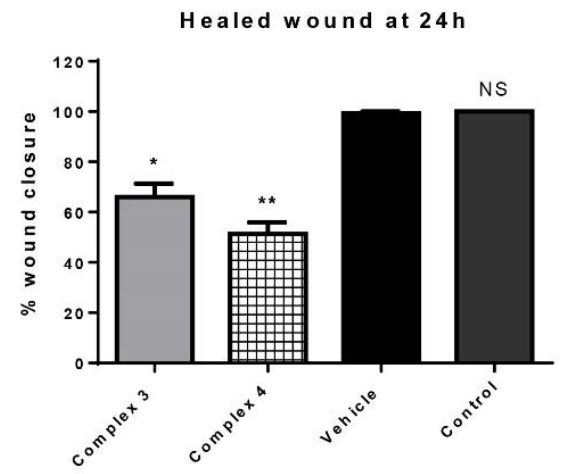

Figure 6 Migratory ability of HECV after CORM treatments. A. Representative images from a traditional scratch wound assay in HECV cells at $0 \mathrm{~h}, 8 \mathrm{~h}$ and $24 \mathrm{~h}$ after treatment with $100 \mu \mathrm{M} \mathrm{CORMs}$ or vehicle or normal media. Objective $5 x$, Scale bar $=100.37 \mu \mathrm{m}$. B. Assessment of the healing, expressed as \% open wound, at all the tested time points after treatment. Graph shows \% open wound $\pm S E M ; n=3, N=3$. All data was statistically analysed against vehicle treated cells using two- 
way ANOVA: * $p<0.05$. C. Average $\%$ wound closure at the final time point $(24 \mathrm{~h})$ for all treatments. All data was statistically analysed against the vehicle group using un-paired $t$-test with Welch's correction: $* p<0.05, * * p<0.01$

\section{Lower HO-1 expression in TNBC cells after complexes 3 and 4 treatments}

The enzyme responsible for the endogenous production of $\mathrm{CO}(\mathrm{HO}-1)$ is also considered cytoprotective, as it protects the cell against excess reactive oxygen species (ROS) production in conditions of oxidative stress [48]. Any reduction in its expression would possibly sensitize cancer cells towards other chemotherapeutic and anti-angiogenic agents. Therefore, this experiment aimed to investigate if the two new most successful CORMs could disrupt the antioxidant defence system of the cell including $\mathrm{HO}-1$ by affecting its expression.

A similar treatment of $100 \mu \mathrm{M}$ CORMs was administered on MDA-MB-231 cells and a Western blot analysis against HO-1 was used. As observed in Figures 7A and 7B, complexes 3 and 4 could both reduce the expression of HO-1 by $\approx 20 \%$ after $12 \mathrm{~h}$ of treatment reaching statistical significance. 


\section{A.}

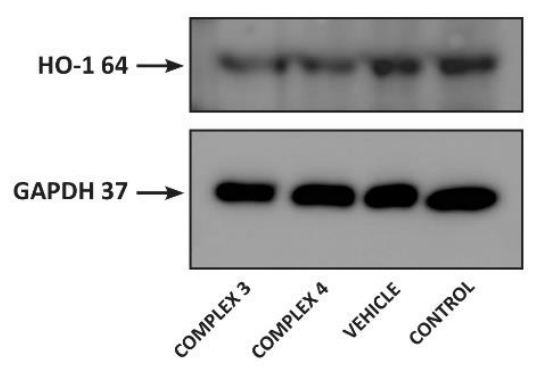

B.

HO-1 expression

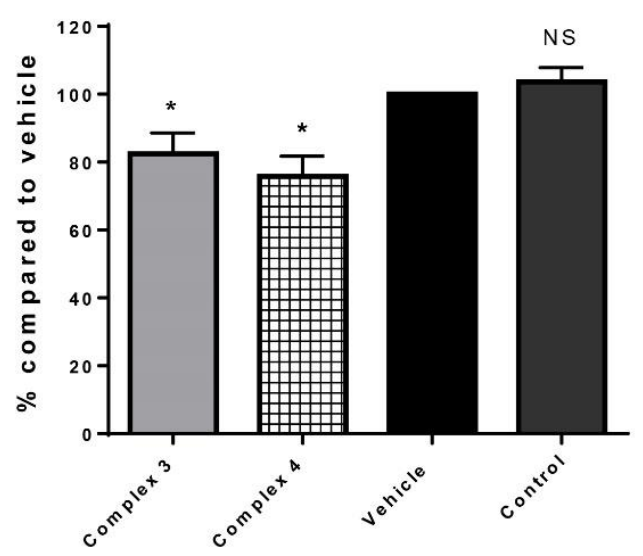

Figure 7 HO-1 expression in MDA-MB-231 after CORM treatments. A. Western blot of HO-1 expression following $100 \mu \mathrm{M}$ CORM or vehicle or media treatment for $12 \mathrm{~h}$ in MDA-MB-231 cells (blots show representative data; $\mathrm{N}=3$ ). B. Assessment of HO-1 levels in MDA-MB-231 cells after treatments. Graph shows \% compared to vehicle +SEM; N=3. Data statistically analysed using nonparametric (Mann-Whitney) $t$-test with * $p<0.05$

\section{DISCUSSION}

A group of 15 new CORMs and the lead complex CORM-3 were synthesized starting from the commercially available CORM-2 and different amino acids, following previous literature methods $[18,38]$. CORM-3 was synthesized and subsequently compared to the commercially available sample via ${ }^{1} \mathrm{H},{ }^{13} \mathrm{C}$ and $\mathrm{HRMS}$ spectra and deemed adequately similar (SupFig 1). 
A.

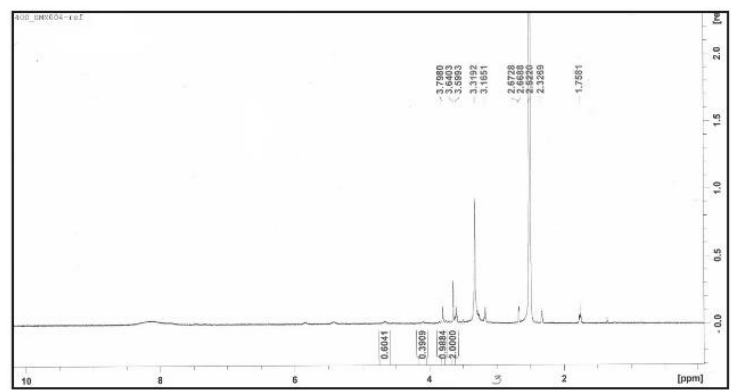

B.

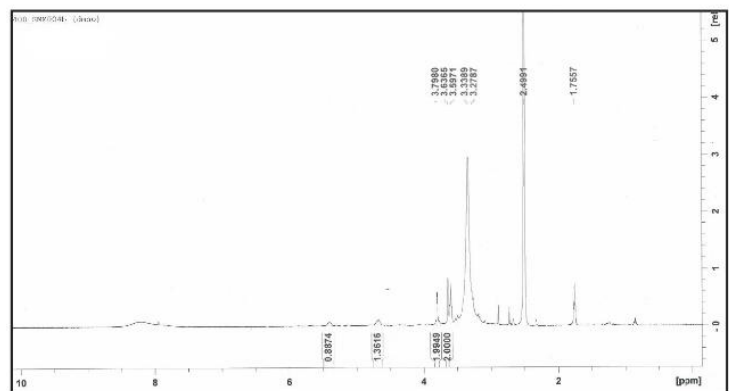

c.

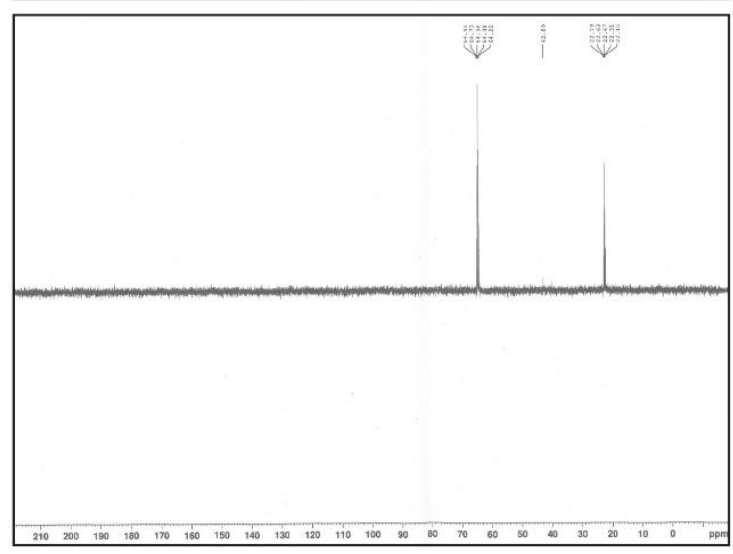

D.

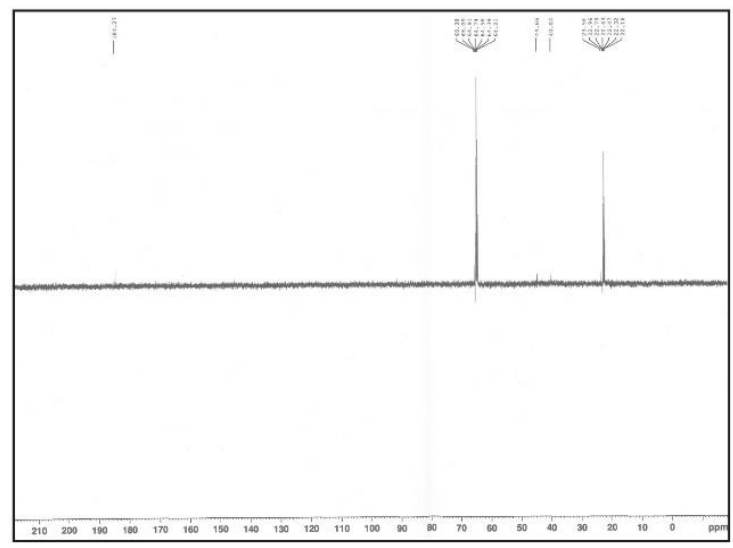

Supplementary Figure 1 Spectra of purchased and synthesized CORM-3 A. ${ }^{1} \mathrm{H}$ NMR spectrum of purchased CORM-3 in THF- $d_{8}$. B. ${ }^{1} \mathrm{H}$ NMR spectrum of synthesized CORM-3 in THF- $d_{8}$. C. ${ }^{13} \mathrm{C}$ NMR spectrum of purchased CORM-3 in THF- $d_{8}$. D. ${ }^{13} \mathrm{C}$ NMR spectrum of synthesized CORM-3 in THF- $d_{8}$ 
An unexpected observation was reported for the ${ }^{13} \mathrm{C}$ NMR spectra of all the complexes which appeared to produce more peaks as the scan number was increased. These peaks appeared in the area of the original projected peaks, which led us to believe that these complexes exist as higher polymers instead of a monomer, as suggested also by previous literature. Another possible explanation for this observation could be a potential change in the molecule while in the NMR tube, maybe as a consequence of its interaction with the solvent or other impurities or because of an extensive aqueous chemistry $[49,20,50]$.

Three of the synthesized CORMs have been reported before in the literature. In the work of Kunz et al. [50] complex $\mathbf{3}$ was synthesized for comparison purposes with its functionalized counterpart on the surface of maghemite nanoparticles. In the work of Wang et al. [38] several CORM-3 derivatives were synthesized and evaluated, including complexes $\mathbf{2}$ and $\mathbf{3}$. Finally, complex $\mathbf{5}$ has been briefly mentioned in a patent that was not readily available at the time of the production of this article.

Finally, the synthesized ligand MK4a was successfully produced in good yield using known reaction schemes (Scheme 2). 
A.
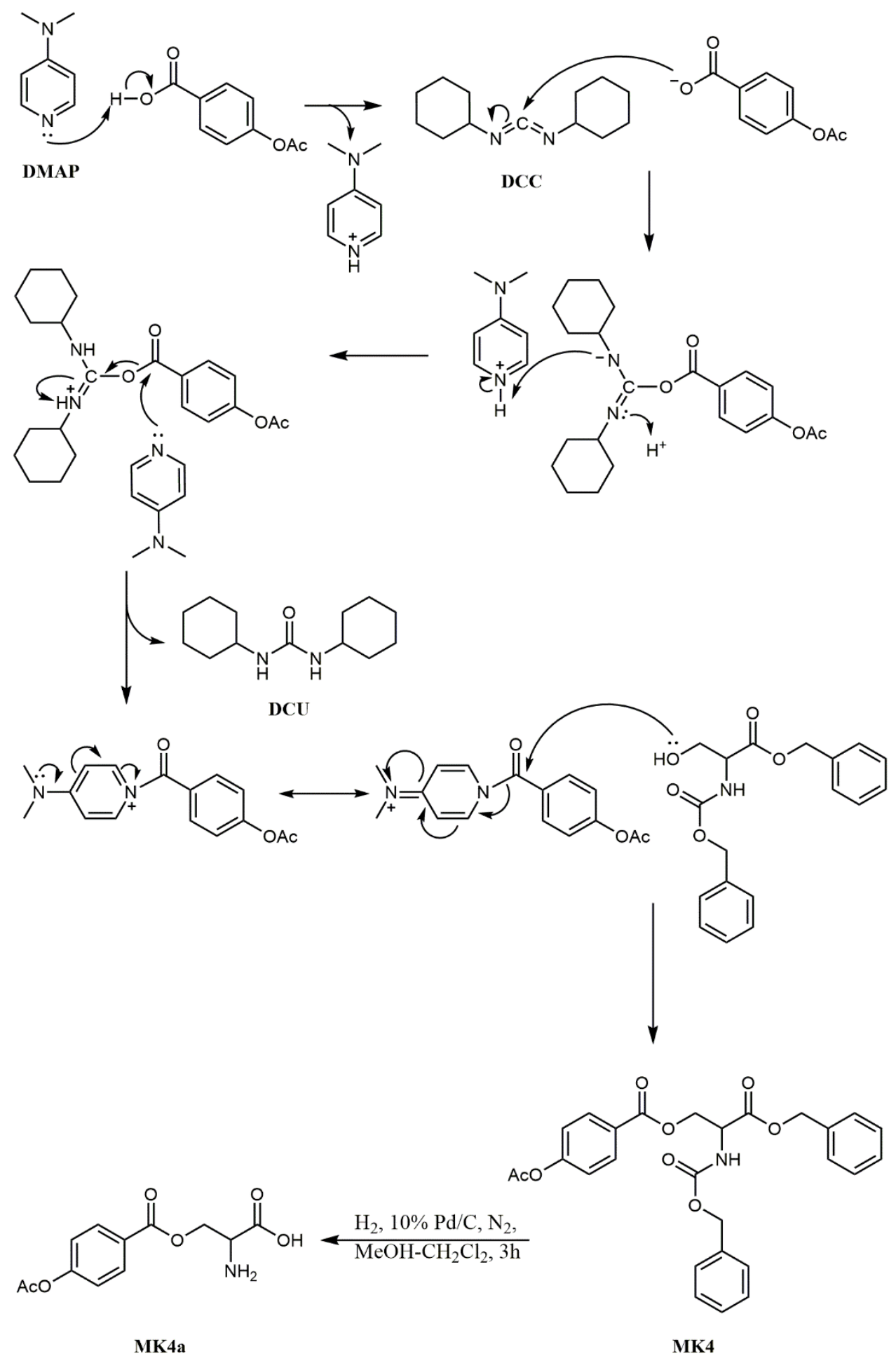

Scheme 2 Synthetic pathway of MK4a ligand. A. Steglich esterification for the synthesis of MK4.

B. Hydrogenolysis for the synthesis of MK4a 
As observed, all the complexes have polar characteristics and their cLogP values are negative, with complex $\mathbf{7}$ having the most hydrophilic and complex $\mathbf{1 1}$ the most lipophilic structures. However, complexes 2, 3, 9 and $\mathbf{1 0}$ share the same tPSA with the lead complex 1. The other CORMs have more extended polar areas and the one with the highest tPSA is complex $\mathbf{1 3}$, due to its two nitro groups.

The new complexes were subsequently evaluated in vitro in order to reveal any antiangiogenic activities against TNBC. This study was based on previous literature suggesting a potential anti-angiogenic behaviour of early CORMs [27] and aimed to measure the effectiveness of the new molecules compared to the lead complex CORM-3.

First of all, the toxicity of the new complexes was evaluated, as the preclinical toxicity testing is a necessary step for all new drug-like molecules, as determined by the FDA [51]. Any potential cytotoxicity of the novel compounds may be related to their capability to release $\mathrm{CO}$, a lethal gas, as well as their metal core, that could also be responsible for toxicity [44].

Therefore, all the 15 newly synthesized candidates were screened against the aggressive MDA-MB-231 TNBC cell line. The most potent analogues were also screened against immortalized vascular endothelial (HECV) and breast epithelial (MCF-10A) cells by the colorimetric MTT assay and proved to have moderate cytotoxicity. However, complexes 2, 7, 12 and 13 were more potent than the parent compound [27]. This was expected for complexes 12 and 13, since nitro compounds are known toxicants that share toxicological effects with aromatic amines, because the nitro group can be readily partially reduced to hydroxyamine derivatives that can yield reactive intermediates after metabolic activation leading to toxicity [52]. However, both complexes were also toxic against the breast epithelial MCF-10A cells, hence no selectivity was observed for these CORMs making them inappropriate candidates for further study. Complexes 2, 7 and 16, on the other hand, had a more favourable selectivity profile having higher cytotoxicity against MDA-MB-231 cells compared to ECs or MCF-10A. 
Tumour angiogenesis is linked to the expression of several proteins that play various roles in pro-angiogenic signalling and the formation of new capillaries. The first important event of malignant angiogenesis is the expression of high concentrations of VEGF by the cancer cells and the second is the successful transduction of the proangiogenic signal starting from the EC surface receptor VEGFR2, in order to stimulate the angiogenic behaviour in ECs. Therefore, the first relevant investigation was the measurement of the VEGF levels expressed by TNBC cells after treatment with all new CORMs at three different time points. Some in vitro models showed an upregulation of VEGF mediated by CORMs as reported previously [53-56], but other studies found an opposite effect for these complexes $[28,27]$.

When the aggressive MDA-MB-231 cell line was treated with the new CORMs for $6 \mathrm{~h}$, $12 \mathrm{~h}$ and $24 \mathrm{~h}, \mathrm{VEGF}$ secretion was found to be reduced and this reduction was evident for all compounds, which for some of them managed to reach statistical significance. The percentage of decrease though reached similar levels as for the parent complex, around $45-65 \%$, with complex 4 being more potent than the parent complex at $6 \mathrm{~h}$ and $24 \mathrm{~h}$ [27]. This suggests that most of the new complexes retain this activity, suggesting that the substitution of glycine with other amino acid moieties did not impair the ability to interfere with the VEGF expression from TNBC cells, possibly also decreasing the stimulation signals to the surrounding ECs. However, no significant enhancement of this effect was observed either.

Following this experiment, complexes $\mathbf{3}$ and $\mathbf{4}$ were considered the most successful among the 15 new analogues. First, they were not considerably cytotoxic and second, they managed to reduce the excreted VEGF levels more than other CORMs for at least two of the three time points tested. The other successful CORMs for each time point, that is complexes $\mathbf{2}, \mathbf{1 4}, \mathbf{1 1}, \mathbf{1 2}$ and $\mathbf{7}$, appeared in the group of the three most efficient CORMs only once and were therefore not pursued further. However, complexes $\mathbf{2}$ and 7 in particular require more investigation due to their favourable characteristic of selective toxicity against TNBC.

The two chosen CORMs were subsequently subjected to experiments investigating inhibitory activity on the VEGF/VEGFR2 pathway of ECs. As a successful pro- 
angiogenic signal transduction is linked to the effective new capillary formation, this pathway was explored as a potential target of the new molecules.

Firstly, the activation of VEGFR2 upon stimulation with VEGF was explored, using the sensitive ELISA technique and Western blot analysis for the quantification of the results. Only complex $\mathbf{4}$ showed a significant trend of reducing the activation of this receptor at Y1175, opposing the activities of complex 3 and the parent CORM-3 [27]. This failure of CORM-3 to inhibit the phosphorylation of VEGFR2 at Y1175 was a drawback for this molecule that complex 4 managed to resolve, since this effect could lead to an inhibition on the pro-angiogenic signal transduction after stimulation with a high dose of VEGF. This result might be linked to the combination of a lower polarity but with a more extended polar area for complex 4 compared to CORM-3. This observation certainly requires further investigation, but if there is a point of interaction between the CORM and the receptor, maybe there is some difficulty for the very polar CORM-3 to reach the surface of the EC, which is no longer problematic upon administration of complex 4.

Moreover, some downstream proteins of VEGFR2 were investigated upon stimulation with VEGF - ERK1/2, Src and FAK - that upon activation are phosphorylated at several sites. It was found that both chosen CORMs had a decreasing activity on the activation of all studied proteins, even though this inhibition was highly successful and statistically significant only for ERK1/2 following the parent complex's behaviour. Again though, complex 4 seemed more successful than CORM-3 reducing the phosphorylation of all of these proteins at higher levels. Especially for the pFAK, complexes $\mathbf{3}$ and $\mathbf{4}$ were both more efficient than complex 1, even though Src and FAK proteins failed to get significantly stimulated, which led to lower significance for the observed results. Complex 3 showed promising results in this experiment but was slightly less effective than complex 4 . In any case, the new CORMs showed better inhibitory activity against proteins of the VEGFR2 pathway than the parent compound CORM-3 [27]. This suggests an enhanced anti-angiogenic activity for the new analogues, as well as a mechanism of action potentially involving the ERK1/2 proteins. In the next step, after the interaction between the VEGF excreted from TNBC cells and the VEGFRs on the surface of ECs, pro-angiogenic pathways are activated and lead to 
new vessel formation by ECs. These ECs will form tubules that will mature into fully functional blood vessels [46]. The in vitro formation of capillary-like structures by ECs seeded on basement matrix has been used as a reliable indication of the potential of different factors to affect angiogenesis [57]. Conditioned media from MDA-MB-231 cells which had been treated with the two chosen novel compounds or vehicle or media for three different durations, was used to stimulate tube formation in HECV cells.

As found, the newly synthesized CORMs seemed to induce a notable reduction in the levels of VEGF expressed by MDA-MB-231 cells. Following this, both CORMs managed to reduce the tube formation activity of ECs to some extent. Conditioned media from complex 3 treated cancer cells caused a modest but significant decrease in the length and complexity of the formed tubes. The same was true also for the conditioned media from complex 4 treated TNBC cells, although it appeared to have a higher activity than complex $\mathbf{3}$ and the reduction especially after treatment with conditioned media from $6 \mathrm{~h}$ pre-treated TNBC cells reached better levels.

These results correlated well with the determined VEGF levels for each conditioned media, and the same trend was observed, that is TNBC cells expressed lower levels of VEGF because of CORM treatments and as a result there was a limited stimulation of ECs towards fewer and less complex tubes. Again complex $\mathbf{4}$ seemed to produce the best results except for the $12 \mathrm{~h}$ time point following the previously shown activity of CORM-3 [27].

In the investigation for direct effects of these complexes on ECs, it appeared that none of them managed to reduce tube formation in a significant manner, reflecting the lack of direct toxicity against HECV and the minimal interference with these cells. Therefore, the effect of reduction on the EC tube formation by these two complexes probably derives from the decreased VEGF levels expressed by the TNBC cells. On the other hand, for both new CORMs there appears to be an additional interference with the VEGFR2 and downstream proteins activation compared to the parent compound. As EC migration is vital for angiogenesis, the two CORMs were studied for disruptive behaviour against the closure of an induced wound in an EC monolayer. Both were 
successful and delayed the closure of the wound for the recorded first $24 \mathrm{~h}$ with comparable efficiency and statistical significance. Again this useful activity of the lead complex was retained in the new derivatives [27].

Finally, HO-1 was deemed an interesting enzyme to study as TNBC cells may be more prone to apoptosis upon limiting their HO-1 expression, which in various cells controls proliferation and growth [58-60]. There was a downregulating activity observed for the two new CORMs that was statistically significant and resembled the lead complex' $\mathrm{s}$ behaviour. This result was particularly welcome, since a decrease in $\mathrm{HO}-1$ expression might lead to more sensitive TNBC cells to chemo- or anti-angiogenic therapies and maybe also promote a less aggressive behaviour of the cancer cells. Once again, the substitution of glycine did not impair this ability of the complex but rather modestly enhanced it [27].

\section{CONCLUSIONS}

In conclusion, it appears that the newly synthesized CORMs generally retained the most important anti-angiogenic activities of the parent compound. One of the most useful results of this study was the downregulation of VEGF expression by TNBC cells which pointed at two specific analogues for further investigation. In three of the six experiments, that is VEGF expression regulation, tube formation upon conditioned media treatment and wound healing through EC migration, the new analogues produced comparable results to the lead complex, CORM-3, as shown in a previous study. Nevertheless, in the other three studies the new molecules were more potent. Specifically, for the downregulation of the VEGFR2 activation at Y1175 only complex 4 was successful, which points towards a very interesting profile for this molecule. The studied proteins of the VEGFR2 pathway were more effectively inhibited by the new complexes than by CORM-3, whereas HO-1 expression reduction was also more profound for the synthesized derivatives.

These observations lead to a very favourable profile for this group of CORMs which can be enhanced even further in order to prove adequately successful against malignant angiogenesis. Complex 4 offers a higher total polar area compared to the parent compound but both complexes $\mathbf{3}$ and $\mathbf{4}$ are more lipophilic. The investigation 
of more molecules of the synthesized group of CORMs will reveal better structureactivity relationships and the exploration of additional potential targets may shed fresh light on the mechanism of action of these special molecules, which appear to combine more than one anti-angiogenic activities.

\section{ACKNOWLEDGEMENTS}

We would like to thank Professor Andrea Brancale for his help and advice throughout this study. We very much appreciate the support of Professor Angela Casini and her group in the School of Chemistry, Cardiff University, for their valuable guidance and advice concerning the synthetic part of this study. We offer special thanks to the Cardiff-China Medical Research Collaborative group for providing the space, consumables and psychological support to complete this work. Finally, the financial aid of the Life Sciences Research Network Wales and Cardiff University is acknowledged.

\section{EXPERIEMENTAL SECTION}

\section{Synthesis of Ligand MK4a}

Preparation of 3-(benzyloxy)-2-(((benzyloxy)carbonyl)amino)-3-oxopropyl 4acetoxybenzoate (MK4)

MK4 was synthesized starting from the commercially available N-benzyloxycarbonylL-serine benzyl ester and 4-acetoxybenzoic acid. The ester ( 1 mol eq, 548.43 mg, 1.665 $\mathrm{mmol}$ ) along with the acid (1 mol eq, $300 \mathrm{mg}, 1.665 \mathrm{mmol}$ ) and dimethylaminepyridine (DMAP) $(0.3 \mathrm{~mol}$ eq, $61.5 \mathrm{mg}, 0.5 \mathrm{mmol})$ were dissolved in dry dichloromethane $(2 \mathrm{~mL})$ in a round-bottomed flask under nitrogen and kept in an ice bath. N,N'-dicyclohexylcarbodiimide (DCC) (1 mol eq, $343.58 \mathrm{mg}, 1.665 \mathrm{mmol}$ ) was dissolved in $6 \mathrm{~mL}$ of dry dichloromethane and added in the flask. After the addition, the reaction was left to stir for $5 \mathrm{~min}$ in ice and for $4 \mathrm{~h}$ at room temperature under nitrogen. The mixture was then filtered to remove the formed dicyclohexylurea (DCU) and the filtrate was concentrated in vacuo. The crude was redissolved in dry dichloromethane, and a new filtration was performed to remove any residual DCU. The filtrate was washed twice with $1 \mathrm{M} \mathrm{HCl}$ and once with $0.1 \mathrm{M} \mathrm{NaOH}$ and the organic 
layer was dried over sodium sulphate for more than $2 \mathrm{~h}$. After the filtration of the sodium sulphate, the solvent was removed in vacuo and the crude was dissolved in isopropanol with gentle heating. The solution was left in the freezer for the final product to crystallize as a white waxy solid (600 $\mathrm{mg}, 73.3 \%$ yield).

${ }^{1}$ H NMR (MeOD, TMS, ppm) $\delta 7.93-7.92$ (d, J= 7Hz, 2H, Ar-H3, H5), $7.34-7.23$ (m, $\left.11 \mathrm{H}, \mathrm{NH}, \mathrm{Ar}-\mathrm{H} 2^{\prime}, \mathrm{H} 3^{\prime}, \mathrm{H}^{\prime}, \mathrm{H} 5^{\prime}, \mathrm{H6} 6^{\prime}, \mathrm{H2}{ }^{\prime \prime}, \mathrm{H} 3^{\prime \prime}, \mathrm{H} 4^{\prime \prime}, \mathrm{H} 5^{\prime \prime}, \mathrm{H6} 6^{\prime \prime}\right) 7.16-7.15$ (d, J= 7Hz, $2 \mathrm{H}, \mathrm{Ar}-\mathrm{H} 2, \mathrm{H} 6), 5.26-5.11\left(\mathrm{~m}, 4 \mathrm{H}, \mathrm{COOC}_{2} \mathrm{Ph}, \mathrm{NHCOOC}_{2} \mathrm{Ph}\right), 4.75-4.56(\mathrm{~m}, 3 \mathrm{H}$, $\left.\mathrm{C}_{2}-\mathrm{C} \underline{\mathrm{H}}\right), 2.34-2.30\left(\mathrm{~m}, 3 \mathrm{H}, \mathrm{CH}_{3}\right) .{ }^{13} \mathrm{C}$ NMR (CDCl $\left.3, \mathrm{TMS}, \mathrm{ppm}\right) \delta 169.33(\mathrm{C}=\mathrm{O}$, $\mathrm{CH}_{3} \underline{\mathrm{COO}}$ ), 168.77 (C=O, $\left.\underline{\mathrm{COOCH}} 2 \mathrm{Ph}\right), 165.09$ (C=O, Ar- $\left.\underline{\mathrm{COO}}-\mathrm{CH}_{2}-\mathrm{CH}\right), 155.70$ (C=O, NHCOOO-CH ${ }_{2} \mathrm{Ph}$ ), 154.59 (Ar-C1), 135.97 (Ar-C1'”), 134.84 (Ar-C1'), 131.92 (2C, Ar-C3, C5), 131.39 (2C, Ar-C3', C5'), 131.30 (2C, Ar-C3"', C5”) 128.64 (2C, Ar-C4', C4") , 128.58 (ArC2') 128.46 (Ar-C6'), 128.31 (Ar-C2'”), 128.19 (Ar-C6"'), 126.73 (Ar-C4), 122.01 (Ar-C2), 121.71 (Ar-C6), 67.86 (NH-COO- $\left.\underline{\mathrm{CH}}_{2} \mathrm{Ph}\right), 67.32\left(\mathrm{CH}-\mathrm{COO}-\underline{\mathrm{CH}}_{2} \mathrm{Ph}\right), 64.86$ (Ar-COO- $\underline{\mathrm{CH}}_{2}-$ $\mathrm{CH}), 53.59(\underline{\mathrm{CH}}), 21.17\left(\underline{\mathrm{C}} \mathrm{H}_{3}\right)$. HRMS-ESI $\mathrm{m} / \mathrm{z}$ Calculated for $\mathrm{C}_{27} \mathrm{H}_{26} \mathrm{NO}_{8}\left[\mathrm{M}+\mathrm{H}^{+}\right]$ 492.1658, found 492.1970 .

\section{Preparation of 0-(4-acetoxybenzoyl)serine (MK4a)}

MK4a was synthesized starting from the synthesized MK4.

MK4 (1 mol eq, $239 \mathrm{mg}, 0.486 \mathrm{mmol}$ ) was dissolved in dry methanol $(5 \mathrm{~mL}$ ) and dry dichloromethane $(1 \mathrm{~mL})$ in a round-bottomed flask. $28 \%$ of the starting material weight in $10 \% \mathrm{Pd} / \mathrm{C}$ were added and the mixture was stirred for a few minutes under nitrogen. The stirring stopped and the nitrogen was replaced with hydrogen and the reaction was left to stir at room temperature for $3 \mathrm{~h}$ under hydrogen ( 1 atmosphere). The mixture was then filtered through a pad of Celite and washed several times with dry methanol. The filtrate and the washings were combined and concentrated in vacuo to yield the final product MK4a as a white solid (100 mg, 77\% yield).

${ }^{1}$ H NMR (MeOD, TMS, ppm) $\delta 8.17-8.15$ (d, $\left.J=9 \mathrm{~Hz}, 2 \mathrm{H}, \mathrm{Ar}-\mathrm{H} 5, \mathrm{H} 3\right) 7.27-7.25$ (d, $J$ $=9 \mathrm{~Hz}, 2 \mathrm{H}, \mathrm{Ar}-\mathrm{H} 2, \mathrm{H} 6) 4.79-4.76\left(\mathrm{dd}, J=3 \mathrm{~Hz}, 12 \mathrm{~Hz}, 1 \mathrm{H}, \mathrm{C}_{2}\right) 4.69-4.66(\mathrm{dd}, J=6.5 \mathrm{~Hz}$, $\left.12.5 \mathrm{~Hz}, 1 \mathrm{H}, \mathrm{C}_{2}\right) 4.03-4.01(\mathrm{~m}, 1 \mathrm{H}, \mathrm{C} \underline{\mathrm{H}}) 2.32\left(\mathrm{~s}, 3 \mathrm{H}, \mathrm{CH}_{3}\right) .{ }^{13} \mathrm{C}$ NMR (MeOD, TMS, ppm) $\delta 169.38$ ( $\mathrm{C}=\mathrm{O}$ acid) 169.07 (C=O Ac) 165.36 (C=O ester) $154.95(\mathrm{Ar}-\mathrm{C} 1) 131.07$ (Ar-C3, 
C5) 126.83 (Ar-C4) 121.59 (Ar-C2, C6) $63.69\left(\underline{\mathrm{CH}}_{2}\right) 53.90(\underline{\mathrm{CH}}) 19.49\left(\underline{\left.\mathrm{CH}_{3}\right)}\right.$ ). HRMS-ESI $\mathrm{m} / \mathrm{z}$ Calculated for $\mathrm{C}_{12} \mathrm{H}_{14} \mathrm{NO}_{6}\left[\mathrm{M}+\mathrm{H}^{+}\right] 268.0821$, found 268.0820 .

\section{Standard procedure for CORM synthesis}

The new analogues were synthesized starting from the commercially available tricarbonyl dichloro ruthenium(II) dimer (CORM-2) $\left[\mathrm{Ru}(\mathrm{CO})_{3} \mathrm{Cl}_{2}\right]_{2}$. In general, CORM-2 (1.0mol equivalent), the appropriate amino acid ( $2.0 \mathrm{~mol}$ equivalent) and sodium methoxide (2.0 mol equivalent) ( $\mathrm{MeONa}$ ) were suspended in dry methanol $(\mathrm{MeOH}$ ) in a round-bottomed flask at room temperature under nitrogen atmosphere maintained by a Schlenk line, and the reaction was allowed to stir for $24 \mathrm{~h}$ at room temperature and protected from light. The solvent was removed in vacuo and the yellow residue re-dissolved in dry THF; this was filtered and then precipitated with excess diethyl ether or light petroleum ether $(40-60)$. The new CORMs were stored in closed vials at $-20^{\circ} \mathrm{C}$ and used fresh on the day of the experiments [18].

\section{Preparation of Tricarbonyl chloro (glycinato) ruthenium(II) (CORM-3) (1) [18]}

CORM-2 $\left[\mathrm{Ru}(\mathrm{CO})_{3} \mathrm{Cl}_{2}\right]_{2}$ (1 mol eq, $100 \mathrm{mg}, 0.195 \mathrm{mmol}$ ), glycine $(2.05 \mathrm{~mol}$ eq, $30 \mathrm{mg}$, $0.4 \mathrm{mmol}$ ) and sodium methoxide $(2.1 \mathrm{~mol} \mathrm{eq}, 22.16 \mathrm{mg}, 0.41 \mathrm{mmol})$ were dissolved in dry methanol $(7 \mathrm{~mL})$ in a round-bottomed flask at room temperature under nitrogen. The reaction was allowed to continue under stirring for $24 \mathrm{~h}$ under nitrogen, at room temperature and protected from light. The solvent was then removed in vacuo and the yellow residue re-dissolved in dry THF $(1 \mathrm{~mL})$; this was filtered through a syringe filter (Nylon) and excess light petroleum ether added. The yellow cloudy solution was evaporated down to give a pale yellow solid (45 mg, 39\% yield). Compound 1 was stored in closed vials at $-20^{\circ} \mathrm{C}$ and used fresh on the day of the experiments.

${ }^{1} \mathrm{H}$ NMR (DMSO- $d_{6}$, TMS, ppm) $\delta 3.64-3.60\left(\mathrm{~m}, 2 \mathrm{H}, \mathrm{C}_{2}\right) .{ }^{1} \mathrm{H}$ NMR $\left(\mathrm{THF}-d_{8}, \mathrm{TMS}, \mathrm{ppm}\right)$ $\delta 5.81$ (s broad, $1 \mathrm{H}, \mathrm{N} \underline{\mathrm{H}}$ ) 5.14 (s broad, $1 \mathrm{H}, \mathrm{N} \underline{\mathrm{H}}) 4.70-4.59(\mathrm{~m}, 1 \mathrm{H}, \underline{\mathrm{CH}}) 3.90-3.88(\mathrm{~m}$, $1 \mathrm{H}, \mathrm{C} \underline{\mathrm{H}}$ ). ${ }^{13} \mathrm{C}$ NMR (THF- $\left.d_{8}, \mathrm{TMS}, \mathrm{ppm}\right) \delta 44.66\left(\underline{\mathrm{CH}}_{2}\right) 184.27$ (C=O). HRMS-ESI $\mathrm{m} / \mathrm{z}$ Calculated for $\mathrm{C}_{5} \mathrm{H}_{4} \mathrm{ClNO}{ }_{5} \mathrm{RuNa}\left[\mathrm{M}+\mathrm{Na}^{+}\right] 317.8719$, found 317.6510. Calculated for $\mathrm{C}_{5} \mathrm{H}_{3} \mathrm{ClNO}_{5} \mathrm{Ru}\left[\mathrm{M}-\mathrm{H}^{+}\right]$293.8743, found 293.6030 . 
Complexes 2-16 were synthesized following the same procedure as for complex $\mathbf{1}$ but changing the amino acid ligand.

Preparation of Tricarbonyl chloro (alaninato) ruthenium(II) (CORM-Ala) (2)

Complex $\mathbf{2}$ was isolated as a yellow solid (95 mg, 90\% yield).

${ }^{1} \mathrm{H}$ NMR (DMSO- $\left.d_{6}, \mathrm{TMS}, \mathrm{ppm}\right) \delta 8.4$ (broad s, $2 \mathrm{H}, \mathrm{NH}_{2}$ ) $3.77-3.72(\mathrm{q}, J=7 \mathrm{~Hz}, 1 \mathrm{H}, \mathrm{C} \underline{\mathrm{H}}$ ) $1.38-1.36\left(\mathrm{~d}, J=7 \mathrm{~Hz}, 3 \mathrm{H}, \mathrm{CH}_{3}\right) .{ }^{1} \mathrm{H}$ NMR (THF- $\left.d_{8}, \mathrm{TMS}, \mathrm{ppm}\right) \delta 3.62-3.59(\mathrm{~m}, 1 \mathrm{H}, \underline{\mathrm{C}}$ ) $1.40-1.15\left(\mathrm{~m}, 3 \mathrm{H}, \mathrm{CH}_{3}\right) .{ }^{13} \mathrm{C}$ NMR (DMSO- $\left.d_{6}, \mathrm{TMS}, \mathrm{ppm}\right) \delta 199.21,197.74,191.01(3 \mathrm{x}$ CO), $181.24(\mathrm{C}=\mathrm{O}), 50.95(\underline{\mathrm{C}} \mathrm{H}), 20.89\left(\underline{\mathrm{C}}_{3}\right)$. HRMS-ESI $\mathrm{m} / \mathrm{z}$ Calculated for $\mathrm{C}_{6} \mathrm{H}_{6} \mathrm{ClNO}_{5} \mathrm{RuNa}\left[\mathrm{M}+\mathrm{Na}^{+}\right]$331.8876, found 331.9920 .

Preparation of Tricarbonyl chloro (phenylalaninato) ruthenium(II) (CORM-Phe) (3)

Complex 3 was isolated as a pale yellow solid (99 mg, 77.5\% yield).

${ }^{1} \mathrm{H}$ NMR (DMSO- $d_{6}$, TMS, ppm) $\delta 7.37-7.22(\mathrm{~m}, 5 \mathrm{H}, \mathrm{Ar}-\mathrm{H}) 3.22-3.09\left(\mathrm{~m}, 2 \mathrm{H}, \underline{\mathrm{C}}_{2}\right)$ 3.03 - 2.64 (m, 1H, Cㅌ). ${ }^{13} \mathrm{C}$ NMR (DMSO-d, TMS, ppm) $\delta 135.74$ (Ar-C1) 129.95, 129.71, 129.00, 128.80, $127.57(\operatorname{Ar}-\mathrm{C} 2,3,4,5,6) 53.93(\underline{\mathrm{CH}}) 36.35\left(\underline{\mathrm{C}} \mathrm{H}_{2}\right)$. HRMS-ESI $\mathrm{m} / \mathrm{z}$ Calculated for $\mathrm{C}_{12} \mathrm{H}_{10} \mathrm{ClNO} \mathrm{RuNa}_{5}\left[\mathrm{M}+\mathrm{Na}^{+}\right]$407.9189, found 408.000. Calculated for $\mathrm{C}_{12} \mathrm{H}_{11} \mathrm{ClNO}_{5} \mathrm{Ru}\left[\mathrm{M}+\mathrm{H}^{+}\right]$385.9369, found 386.1812.

Preparation of Tricarbonyl chloro (tyrosinato) ruthenium(II) (CORM-Tyr) (4) Complex 4 was isolated as a yellow solid (132 mg, 99.2\% yield).

${ }^{1} \mathrm{H}$ NMR (DMSO-d $\left.d_{6}, \mathrm{TMS}, \mathrm{ppm}\right) \delta 9.41(\mathrm{~s}, 1 \mathrm{H}, \mathrm{OH}), 7.07-7.02(\mathrm{~m}, 2 \mathrm{H}, \mathrm{Ar}-\mathrm{H} 2, \mathrm{H} 6), 6.73$ - $6.65(\mathrm{~m}, 2 \mathrm{H}, \mathrm{Ar}-\mathrm{H} 3, \mathrm{H} 5), 4.15-4.02(\mathrm{~m}, 1 \mathrm{H}, \mathrm{C} \underline{\mathrm{H}}), 3.04-2.95\left(\mathrm{~m}, 2 \mathrm{H}, \mathrm{C}_{2}\right) .{ }^{13} \mathrm{C}$ NMR (DMSO- $d_{6}$, TMS, ppm) $\delta 170.91$ (C=O ester), 157.08 (Ar-C4), 130.96, 130.72 (Ar-C2, C6), 125.21 (Ar-C1), 115.84, 115.64 (Ar-C3, C5), $53.98(\underline{\mathrm{C}} \mathrm{H}), 35.5\left(\underline{\mathrm{CH}}_{2}\right)$. HRMS-ESI $m / z$ Calculated for $\mathrm{C}_{12} \mathrm{H}_{11} \mathrm{CINO}_{6} \mathrm{Ru}\left[\mathrm{M}+\mathrm{H}^{+}\right]$401.9318, found 402.3089 .

Preparation of Tricarbonyl chloro (serinato) ruthenium(II) (CORM-Ser) (5)

Complex 5 was isolated as a yellow solid (34 mg, 32\% yield).

${ }^{1} \mathrm{H}$ NMR (DMSO-d $\left.d_{6}, \mathrm{TMS}, \mathrm{ppm}\right) \delta 8.78-7.80$ (s broad, $2 \mathrm{H}, \mathrm{N}_{2}$ ) $3.81-3.69(\mathrm{~m}, 2 \mathrm{H}$, $\mathrm{C}_{2}$ ). ${ }^{13} \mathrm{C}$ NMR (DMSO- $\left.d_{6}, \mathrm{TMS}, \mathrm{ppm}\right) \delta 169.85(\mathrm{C}=\mathrm{O}) 60.21\left(\underline{\mathrm{CH}}_{2}\right) 55.32$ (다). HRMS- 
ESI $m / z$ Calculated for $\mathrm{C}_{6} \mathrm{H}_{6} \mathrm{ClNO}_{6} \mathrm{RuNa}\left[\mathrm{M}+\mathrm{Na}^{+}\right]$347.8825, found 347.8010. Calculated for $\mathrm{C}_{6} \mathrm{H}_{7} \mathrm{ClNO}_{6} \mathrm{Ru}\left[\mathrm{M}+\mathrm{H}^{+}\right]$325.9005, found 325.8317.

\section{Preparation of Tricarbonyl chloro (aspartato) ruthenium(II) (CORM-Asp) (6)}

Complex 6 was isolated as a yellow solid (115mg, 98.2\% yield). CORM-Asp was stored in closed vials at $-20^{\circ} \mathrm{C}$ and used freshly on the day of the experiments.

${ }^{1} \mathrm{H}$ NMR (DMSO- $\left.d_{6}, \mathrm{TMS}, \mathrm{ppm}\right) \delta 8.34\left(\mathrm{~s}\right.$ broad, $\left.2 \mathrm{H}, \mathrm{N}_{2}\right) 4.08-4.06(\mathrm{t}, J=5.5 \mathrm{~Hz}, 1 \mathrm{H}$, Cㅡㅡ) $2.85-2.83\left(\mathrm{~m}, 2 \mathrm{H}, \mathrm{C}_{2}\right) .{ }^{13} \mathrm{C}$ NMR (DMSO- $\left.d_{6}, \mathrm{TMS}, \mathrm{ppm}\right) \delta 196.28,191.02,187.02$ (3x CO) 171.40 (C=O ester) 170.48 (C=O acid) $51.67(\underline{\mathrm{CH}}) 35.08$ ( $\mathrm{C}_{2}$ ). HRMS-ESI $\mathrm{m} / \mathrm{z}$ Calculated for $\mathrm{C}_{6} \mathrm{H}_{5} \mathrm{ClNO}_{6} \mathrm{Ru}\left[\mathrm{M}-\mathrm{CO}-\mathrm{H}^{+}\right]$323.8849, found 323.9198.

\section{Preparation of Tricarbonyl chloro (histidinato) ruthenium(II) (CORM-His) (7)}

Complex 7 was isolated as an off-white solid ( $75 \mathrm{mg}, 60 \%$ yield).

${ }^{1}$ H NMR (DMSO- $d_{6}$, TMS, ppm) $\delta 13.15-13.00(\mathrm{~m}, 1 \mathrm{H}, \mathrm{NH}), 8.09-7.85(\mathrm{~m}, 1 \mathrm{H}, \mathrm{Ar}-$ $\mathrm{H} 4), 7.34-7.10(\mathrm{~m}, 1 \mathrm{H}, \mathrm{Ar}-\mathrm{H} 2), 3.91-3.85(\mathrm{~m}, 1 \mathrm{H}, \mathrm{C} \underline{\mathrm{H}}) 3.27-3.19\left(\mathrm{~m}, 1 \mathrm{H}, \mathrm{CH}_{2}\right) 3.06$ - $3.01\left(\mathrm{~m}, 1 \mathrm{H}, \mathrm{CH}_{2}\right) .{ }^{13} \mathrm{C}$ NMR (DMSO- $\left.d_{6}, \mathrm{TMS}, \mathrm{ppm}\right) \delta 203.24,202.47,201.41$ (3x CO) 180.84 (C=O ester) 140.89 (Ar-C4) 134.71 (Ar-C1) 115.31 (Ar-C2) 52.44 (ㅁH) 28.27 $\left(\underline{\mathrm{C}} \mathrm{H}_{2}\right)$. HRMS-ESI $m / z$ Calculated for $\mathrm{C}_{9} \mathrm{H}_{7} \mathrm{ClN}_{3} \mathrm{O}_{5} \mathrm{Ru}\left[\mathrm{M}-\mathrm{H}^{+}\right]$373.9118, found 373.8530 .

\section{Preparation of Tricarbonyl chloro (tryptophanato) ruthenium(II) (CORM-Trp) (8)}

Complex 8 was isolated as a pale yellow solid ( $100 \mathrm{mg}, 71 \%$ yield).

${ }^{1} \mathrm{H}$ NMR (DMSO- $d_{6}$, TMS, ppm) $\delta 11.13-10.93(\mathrm{~m}, 1 \mathrm{H}, \mathrm{NH}), 7.61-7.52(\mathrm{~m}, 1 \mathrm{H}, \mathrm{Ar}-$ H7), 7.40 - 7.33 (m, 1H, Ar-H4), 7.26 - 7.19 (m, 1H, Ar-H2), 7.11 - 6.96 (m, 2H, Ar-H6, H5) $4.31-4.00(\mathrm{~m}, 1 \mathrm{H}, \underline{\mathrm{CH}}) 3.30-2.91\left(\mathrm{~m}, 2 \mathrm{H}, \mathrm{C}_{2}\right) .{ }^{1} \mathrm{H}$ NMR (THF- $\left.d_{8}, \mathrm{TMS}, \mathrm{ppm}\right) \delta$ $10.25-10.13(\mathrm{~m}, 1 \mathrm{H}, \mathrm{NH}), 7.66-7.61(\mathrm{~m}, 1 \mathrm{H}, \mathrm{Ar}-\mathrm{H} 7), 7.39-7.28(\mathrm{~m}, 2 \mathrm{H}, \mathrm{Ar}-\mathrm{H} 4, \mathrm{H} 2)$, $7.14-6.97(\mathrm{~m}, 2 \mathrm{H}, \mathrm{Ar}-\mathrm{H} 6, \mathrm{H} 5) 4.09-3.83(\mathrm{~m}, 1 \mathrm{H}, \mathrm{C} \underline{\mathrm{H}}) 3.61-3.18\left(\mathrm{~m}, 2 \mathrm{H}, \mathrm{C}_{2}\right) .{ }^{13} \mathrm{C}$ NMR (THF- $d_{8}$, TMS, ppm) $\delta 135.17$ (Ar-C3) 126.02 (Ar-C8) 122.07 (Ar-C2) 119.38 (ArC5) 116.83 (Ar-C6) 116.34 (Ar-C7) 109.18 (Ar-C4) 107.74 (Ar-C1) 53.57 (ㅁH) 27.06 $\left(\underline{\mathrm{C}} \mathrm{H}_{2}\right)$. HRMS-ESI $\mathrm{m} / z$ Calculated for $\mathrm{C}_{13} \mathrm{H}_{11} \mathrm{ClN}_{2} \mathrm{O}_{4} \mathrm{RuNa}\left[\mathrm{M}-\mathrm{CO}+\mathrm{Na}^{+}\right] 418.9349$, found 419.0381. 
Preparation of Tricarbonyl chloro (cyclopentanato) ruthenium(II) (CORM-

Cyclopent) (9)

Complex 9 was isolated as a pale yellow solid (67 mg, 57.8\% yield).

${ }^{1} \mathrm{H}$ NMR (DMSO- $\left.d_{6}, \mathrm{TMS}, \mathrm{ppm}\right) \delta 8.5$ (broad, $\left.2 \mathrm{H}, \mathrm{N}_{2}\right) 2.08-1.73\left(\mathrm{~m}, 8 \mathrm{H},\left(\mathrm{C}_{2}\right)_{4}\right) .{ }^{13} \mathrm{C}$ NMR (DMSO- $d_{6}$, TMS, ppm) $\delta$ 201.30, 186.99, 185.11 (3x CO), 174.43 (C=O ester), 64.79 (C1), $36.58\left(2 \mathrm{C}, \underline{\mathrm{CH}}_{2}(2,5)\right), 25.55\left(2 \mathrm{C}, \underline{\mathrm{CH}}_{2}(3,4)\right)$. HRMS-ESI $\mathrm{m} / \mathrm{z}$ Calculated for $\mathrm{C}_{9} \mathrm{H}_{9} \mathrm{ClNO}_{5} \mathrm{Ru}\left[\mathrm{M}-\mathrm{H}^{+}\right]$347.9213, found 347.9488.

Preparation of Tricarbonyl chloro (cyclohexanato) ruthenium(II) (CORM-Cyclohex) (10)

Complex 10 was isolated as a pale yellow solid ( $87 \mathrm{mg}, 72.3 \%$ yield).

${ }^{1} \mathrm{H}$ NMR (DMSO- $\left.d_{6}, \mathrm{TMS}, \mathrm{ppm}\right) \delta 8.5\left(\mathrm{~s}\right.$ broad, $\left.2 \mathrm{H}, \mathrm{N}_{2}\right) 1.93-1.34\left(\mathrm{~m}, 10 \mathrm{H},\left(\mathrm{C}_{2}\right)_{5}\right)$. ${ }^{13} \mathrm{C}$ NMR (DMSO- $\left.d_{6}, \mathrm{TMS}, \mathrm{ppm}\right) \delta 191.02$ (CO), 65.37 (C1), $35.45\left(\underline{\mathrm{C}} \mathrm{H}_{2}(6)\right), 31.89\left(\underline{\mathrm{CH}}_{2}\right.$ (2)), $24.83\left(\underline{\mathrm{CH}}_{2}(4)\right), 20.99\left(\underline{\mathrm{CH}}_{2}(3)\right), 20.67\left(\underline{\mathrm{CH}}_{2}(5)\right)$. HRMS-ESI $\mathrm{m} / z$ Calculated for $\mathrm{C}_{10} \mathrm{H}_{11} \mathrm{ClNO}_{5} \mathrm{Ru}\left[\mathrm{M}-\mathrm{H}^{+}\right]$361.9369, found 361.9510 .

Preparation of Tricarbonyl chloro (O-benzyloserinato) ruthenium(II) (CORM-BenzSer) (11)

Complex 11 was isolated as a pale yellow solid ( $120 \mathrm{mg}, 87.1 \%$ yield).

${ }^{1} \mathrm{H}$ NMR (THF- $d_{8}$, TMS, ppm) $\delta 7.36-7.22(\mathrm{~m}, 5 \mathrm{H}, \mathrm{Ar}-\mathrm{H}) 4.62-4.47\left(\mathrm{~m}, 2 \mathrm{H}, \mathrm{CH}_{2}-2\right) 3.95$ - 3.69 (m, 3H, $\left.\underline{\mathrm{C}}_{2}-1, \mathrm{CH}\right) .{ }^{13} \mathrm{C}$ NMR (THF- $\left.d_{8}, \mathrm{TMS}, \mathrm{ppm}\right) \delta 187.4,185.16,182.98(3 \mathrm{x}$ CO), 175.34 ( $\mathrm{C}=\mathrm{O}$ ester) 136.36 (Ar-C1), 126.12 (Ar-C5) 126.06 (Ar-C3) 125.75 (Ar-C6) 125.68 (Ar-C2) 125.44 (Ar-C4) $71.20\left(\underline{C^{2}} \mathrm{H}_{2}-2\right) 69.57\left(\underline{\mathrm{CH}}_{2}-1\right) 53.35(\underline{\mathrm{C}} \mathrm{H})$. HRMS-ESI $\mathrm{m} / \mathrm{z}$ Calculated for $\mathrm{C}_{13} \mathrm{H}_{11} \mathrm{ClNO}_{6} \mathrm{Ru}\left[\mathrm{M}-\mathrm{H}^{+}\right]$413.9318, found 413.7597 .

Preparation of Tricarbonyl chloro (3-nitrotyrosinato) ruthenium(II) (CORM-NitroTyr) (12)

Complex 12 was isolated as a yellow solid (112 mg, 75.6\% yield).

${ }^{1} \mathbf{H}$ NMR (MeOD, TMS, ppm) $\delta 8.14-8.04(\mathrm{~m}, 1 \mathrm{H}, \mathrm{Ar}-\mathrm{H} 2) 7.66-7.58(\mathrm{~m}, 1 \mathrm{H}, \mathrm{Ar}-\mathrm{H} 6)$ $7.19-7.12(\mathrm{~m}, 1 \mathrm{H}, \mathrm{Ar}-\mathrm{H} 5) 3.99-3.93(\mathrm{~m}, 1 \mathrm{H}, \mathrm{C} \underline{\mathrm{H}}) 3.40-3.35\left(\mathrm{~m}, 1 \mathrm{H}, \mathrm{C}_{2}\right) 3.26-2.96$ 
(m, 1H, $\underline{\mathrm{C}}_{2}$ ). ${ }^{13} \mathrm{C}$ NMR (MeOD, TMS, ppm) $\delta$ 187.77, 186.01, 184.06 (3x CO) 181.77 (C=O ester) 153.26 (Ar-C4) 137.64 (Ar-C6) 129.01 (Ar-C3) 128.70 (Ar-C1) 125.42 (ArC2) 120.09 (Ar-C5) 56.60 (마) $37.54\left(\underline{\mathrm{CH}}_{2}\right)$. HRMS-ESI $\mathrm{m} / \mathrm{z}$ Calculated for $\mathrm{C}_{12} \mathrm{H}_{8} \mathrm{ClN}_{2} \mathrm{O}_{8} \mathrm{Ru}\left[\mathrm{M}-\mathrm{H}^{+}\right]$444.9013, found 444.9310 .

Preparation of Tricarbonyl chloro (3,5-dinitrotyrosinato) ruthenium(II) (CORMDinitro-Tyr) (13)

Complex 13 was isolated as a dark orange solid ( $120 \mathrm{mg}, 73.7 \%$ yield).

${ }^{1} \mathrm{H}$ NMR (MeOD, TMS, ppm) $\delta 8.20(\mathrm{~s}, 2 \mathrm{H}, \mathrm{Ar}-\mathrm{H} 2, \mathrm{H} 6) 3.92-3.82(\mathrm{~m}, 1 \mathrm{H}, \mathrm{C} \underline{\mathrm{H}}) 3.22-$ $3.103\left(\mathrm{~m}, 2 \mathrm{H}, \mathrm{CH}_{2}\right) .{ }^{13} \mathrm{C}$ NMR (MeOD, TMS, ppm) $\delta 198.47,196.50,188.05$ (3x CO) 186.26 (C=O ester) 148.82 (Ar-C4) 140.00, 139.80 (Ar-C3, C5) 139.47 (Ar-C1) 131.87, 131.53 (Ar-C2, C6) 56.71 ( $\underline{\mathrm{C}} \mathrm{H}) 38.14\left(\underline{\mathrm{C}}_{2}\right)$. HRMS-ESI $\mathrm{m} / \mathrm{z}$ Calculated for $\mathrm{C}_{12} \mathrm{H}_{7} \mathrm{ClN}_{3} \mathrm{O}_{10} \mathrm{Ru}\left[\mathrm{M}-\mathrm{H}^{+}\right]$489.8863, found 490.2033.

Preparation of Tricarbonyl chloro (4-nitrophenylalaninato) ruthenium(II) (CORMNitro-Phe) (14)

Complex 14 was isolated as a yellow solid (135 mg, 94.7\% yield).

${ }^{1} \mathrm{H}$ NMR (DMSO- $d_{6}$, TMS, ppm) $\delta 8.51$ (s broad, $\left.2 \mathrm{H}, \mathrm{N}_{\underline{\mathrm{H}}}\right) 8.22-8.08(\mathrm{~m}, 2 \mathrm{H}, \mathrm{Ar}-\mathrm{H} 3$, H5) $7.71-7.46(\mathrm{~m}, 2 \mathrm{H}, \mathrm{Ar}-\mathrm{H} 2, \mathrm{H} 6) 4.18-4.17(\mathrm{~m}, 1 \mathrm{H}, \mathrm{C} \underline{\mathrm{H}}) 3.09-2.97\left(\mathrm{~m}, 1 \mathrm{H}, \mathrm{C}_{2}\right.$, second hydrogen obscured by traces of $\mathrm{H}_{2} \mathrm{O}$ in the NMR solvent). ${ }^{13} \mathrm{C}$ NMR (DMSO- $d_{6}$, TMS, ppm) $\delta 176.62$ (CO) 170.45 (C=O ester) 147.22 (Ar-C4) $144.22(\mathrm{Ar}-\mathrm{C} 1) 131.45$ (ArC2) 131.28 (Ar-C6) 123.96 (Ar-C3) 123.78 (Ar-C5) 53.43 (마) $35.91\left(\underline{\mathrm{CH}_{2}}\right.$ ). HRMS-ESI $\mathrm{m} / \mathrm{z}$ Calculated for $\mathrm{C}_{12} \mathrm{H}_{8} \mathrm{ClN}_{2} \mathrm{O}_{7} \mathrm{Ru}\left[\mathrm{M}-\mathrm{H}^{+}\right]$428.9064, found 428.7440 .

Preparation of Tricarbonyl chloro (4-aminophenylalaninato) ruthenium(II) (CORMAm-Phe) (15)

Complex 15 was isolated as a pale yellow solid ( $139 \mathrm{mg}, 97.9 \%$ yield).

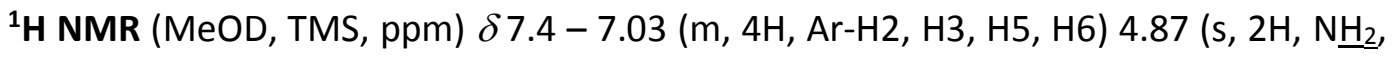
obscured by traces of $\mathrm{H}_{2} \mathrm{O}$ in the NMR solvent) $4.13-3.93(\mathrm{~m}, 1 \mathrm{H}, \mathrm{C} \underline{\mathrm{H}}) 3.30-2.94(\mathrm{~m}$, $\left.2 \mathrm{H}, \mathrm{CH}_{2}\right) .{ }^{13} \mathrm{C}$ NMR (MeOD, TMS, ppm) $\delta 187.74,186.04,184.61$ (3x CO) 183.99 (C=0 ester) 144.42 (Ar-C4) 130.85 (Ar-C6) 130.39 (Ar-C2) 120.90 (Ar-C5) 119.97 (Ar-C3) 
$56.70(\underline{\mathrm{CH}}) 38.07\left(\underline{\mathrm{C}} \mathrm{H}_{2}\right)$. HRMS-ESI $m / z$ Calculated for $\mathrm{C}_{12} \mathrm{H}_{10} \mathrm{CIN}_{2} \mathrm{O}_{5} \mathrm{Ru}\left[\mathrm{M}-\mathrm{H}^{+}\right]$389.9322, found 398.6997.

\section{Preparation of Tricarbonyl chloro (0-(4-acetoxybenzoyl)serinato) ruthenium(II) (CORM-MK4a) (16)}

Complex 16 was isolated as a pale yellow solid ( $156 \mathrm{mg}, 86.6 \%$ yield).

${ }^{1} \mathrm{H}$ NMR $\left(\mathrm{THF}-\mathrm{d}_{8}, \mathrm{TMS}, \mathrm{ppm}\right) \delta 8.22-8.07(\mathrm{~m}, 2 \mathrm{H}, \mathrm{Ar}-\mathrm{H} 2, \mathrm{H} 6) 7.22-7.19(\mathrm{~m}, 2 \mathrm{H}, \mathrm{Ar}-$ $\mathrm{H} 3, \mathrm{H} 5) 4.71-4.65\left(\mathrm{~m}, 2 \mathrm{H}, \mathrm{C}_{2}\right) 4.12-3.98(\mathrm{~m}, 1 \mathrm{H}, \underline{\mathrm{C}} \underline{)}) 2.25\left(\mathrm{~s}, 3 \mathrm{H}, \mathrm{C}_{3}\right) .{ }^{13} \mathrm{C}$ NMR (THF- $d_{8}$, TMS, ppm) $\delta 184.21$ (CO) 174.70 (C=O ester) 165.91 (C=O 2) 163.30 (C=O 1) 153.1 (Ar-C4) 129.32 (Ar-C2) 129.00 (Ar-C6) 125.2 (Ar-C1) 119.75 (Ar-C3) 119.62 (ArC5) peak of $\mathrm{CH}_{2}$ within the solvent signal (expected around 64) $52.68(\underline{\mathrm{CH}}) 17.90\left(\underline{\mathrm{C}} \mathrm{H}_{3}\right)$. HRMS-ESI $m / z$ Calculated for $\mathrm{C}_{15} \mathrm{H}_{11} \mathrm{CINO}_{9} \mathrm{Ru}\left[\mathrm{M}-\mathrm{H}^{+}\right]$485.9166, found 485.5210 .

\section{CAPTIONS}

Table 1 Antibodies used in the study

Table 2 Amino acids as ligands of the new CORMs and the final synthesized complexes with their chemical properties as calculated in ChemDraw Professional 16.0

Table 3 Cytotoxicity of novel CORMs. Mean $\mathrm{IC}_{50}(\mu \mathrm{M})$ values for all compounds and cell lines tested (calculated in GraphPad Prism) ( $n=3, N=3, n . d .=$ not determined)

Scheme 1 Synthesis. Synthetic scheme for CORM-3 analogues and synthesized complexes

Scheme 2 Synthetic pathway of MK4a ligand. A. Steglich esterification for the synthesis of MK4. B. Hydrogenolysis for the synthesis of MK4a

Figure 1 VEGF expression after CORM treatments. A. VEGF expression quantification in MDA-MB231 cells $6 \mathrm{~h}$ after treatment with $100 \mu \mathrm{M}$ CORMs, $0.1 \%$ DMSO or normal media, using a human VEGF ELISA kit. B. VEGF expression quantification in MDA-MB-231 cells $12 \mathrm{~h}$ after treatment with $100 \mu \mathrm{M}$ CORMs, $0.1 \%$ DMSO or normal media, using a human VEGF ELISA kit. C. VEGF expression quantification in MDA-MB-231 cells $24 \mathrm{~h}$ after treatment with $100 \mu \mathrm{M}$ CORMs, $0.1 \%$ DMSO or normal media, using a human VEGF ELISA kit. (All data is presented as \% compared to control $+S E M ; n=3, N=3$ ). All data was statistically analysed against the corresponding duration normal media treated MDA-MB-231 cells (control) using un-paired $t$-test with Welch's correction: ${ }^{*} \mathrm{p}<0.05,{ }^{*} \mathrm{p}<0.01, * * * \mathrm{p}<0.001$. In each time point, the three new CORMs that reduce VEGF expression the most are highlighted in red boxes 
Figure 2 Quantification of pY1175 levels in HUVEC after CORM pre-treatments and VEGF stimulation. A. Expression levels of pY1175 of VEGFR2 in HUVEC after 15min of 100 $\mu$ M CORM or vehicle pre-incubation and then stimulation with VEGF $(100 \mathrm{ng} / \mathrm{ml})$ for $5 \mathrm{~min}$, as measured with the human pY1175-VEGFR2 ELISA kit. The first sample is the unstimulated control (control) and the second is the stimulated control (SFM=serum free media). Graph shows \% compared to control +SEM; $N=3$. Data statistically analysed using unpaired Student's $t$-test with Welch's correction * $p<0.05$. B. Western blot of pY1175 of VEGFR2 following the same protocol, which verifies the results of the ELISA (blots show representative data; $\mathrm{N}=3$ )

Figure 3 Expression of VEGFR2 pathway proteins in HUVEC after CORM pre-treatments and VEGF stimulation. A. Western blot of pFAK, pSrc and pERK1/2 following $100 \mu \mathrm{M}$ CORM or vehicle preincubation and then stimulation with VEGF for $5 \mathrm{~min}$. The first sample is the unstimulated control (control) and the second is the stimulated control (SFM) (blots show representative data; $\mathrm{N}=4$ ). $\mathbf{B}$. Assessment of pFAK, pSrc and pERK1/2 levels in HUVEC. Graphs show \% compared to control +SEM; $\mathrm{N}=4$. Data statistically analysed using nonparametric (Mann-Whitney) $t$-test with $* \mathrm{p}<0.05, * *$ $p<0.01$

Figure 4 Tube formation ability of HECV after cancer conditioned media treatments. A. Representative images from tube formation assay with HECV cells treated with conditioned media from variable duration incubation of MDA-MB-231 cells with $100 \mu \mathrm{M}$ CORMs or $0.1 \%$ DMSO or normal media. Objective $5 x$, Scale bar $=132.08 \mu \mathrm{m}$. B. Assessment of tube formation capacity of HECV cells after conditioned media treatments. Graph shows \% total tube perimeter compared to vehicle $+S E M ; n=3, N=3$. All data was statistically analysed against the conditioned media from corresponding duration vehicle treated MDA-MB-231 cells using un-paired t-test with Welch's correction: $* \mathrm{p}<0.05, * * \mathrm{p}<0.01, * * * \mathrm{p}<0.001$

Figure 5 Tube formation ability of HECV after CORM treatments. A. Representative images from tube formation assay with HECV cells treated with 100 $\mathrm{MM}$ CORMs or 0.1\% DMSO or SFM. Objective $5 \mathrm{x}$, Scale bar $=132.08 \mu \mathrm{m}$. B. Assessment of tube formation capacity of HECV cells after instant CORM treatments. Graph shows \% total tube perimeter compared to vehicle $+S E M ; n=3, N=3$. All data was statistically analysed against vehicle treated cells using un-paired $t$-test with Welch's correction: * $\mathrm{p}<0.05$

Figure 6 Migratory ability of HECV after CORM treatments. A. Representative images from a traditional scratch wound assay in HECV cells at $0 \mathrm{~h}, 8 \mathrm{~h}$ and $24 \mathrm{~h}$ after treatment with $100 \mu \mathrm{M}$ CORMs or vehicle or normal media. Objective $5 x$, Scale bar $=100.37 \mu \mathrm{m}$. B. Assessment of the healing, expressed as \% open wound, at all the tested time points after treatment. Graph shows \% open wound $\pm S E M ; n=3, N=3$. All data was statistically analysed against vehicle treated cells using twoway ANOVA: * $p<0.05$. C. Average $\%$ wound closure at the final time point $(24 \mathrm{~h})$ for all treatments. 
All data was statistically analysed against the vehicle group using un-paired $t$-test with Welch's correction: $* p<0.05, * * p<0.01$

Figure 7 HO-1 expression in MDA-MB-231 after CORM treatments. A. Western blot of HO-1 expression following $100 \mu \mathrm{M}$ CORM or vehicle or media treatment for $12 \mathrm{~h}$ in MDA-MB-231 cells (blots show representative data; $\mathrm{N}=3$ ). B. Assessment of HO-1 levels in MDA-MB-231 cells after treatments. Graph shows \% compared to vehicle +SEM; N=3. Data statistically analysed using nonparametric (Mann-Whitney) $t$-test with * $\mathrm{p}<0.05$

Supplementary Figure 1 Spectra of purchased and synthesized CORM-3 A. ${ }^{1} \mathrm{H}$ NMR spectrum of purchased CORM-3 in THF- $d_{8}$. B. ${ }^{1} \mathrm{H}$ NMR spectrum of synthesized CORM-3 in THF- $d_{8}$. C. ${ }^{13} \mathrm{C}$ NMR spectrum of purchased CORM-3 in THF- $d_{8}$. D. ${ }^{13} \mathrm{C}$ NMR spectrum of synthesized CORM-3 in THF- $d_{8}$

\section{COMPLIANCE WITH ETHICAL STANDARDS}

\section{FUNDING}

This study was funded by the Life Sciences Research Network Wales and Cardiff University (Grant number 509876).

\section{DISCLOSURE OF POTENTIAL CONFLICTS OF INTEREST}

Author A declares that he has no conflict of interest. Author B declares that he has no conflict of interest. Author $\mathrm{C}$ declares that he has no conflict of interest. Author $\mathrm{D}$ declares that he has no conflict of interest.

\section{RESEARCH INVOLVING HUMAN PARTICIPANTS AND/OR ANIMALS}

This article does not contain any studies with human participants or animals performed by any of the authors.

\section{INFORMED CONSENT}

No consent needed. This article does not contain any studies with human participants or animals performed by any of the authors.

\section{REFERENCES}

1. Kalimutho M, Parsons K, Mittal D, López JA, Srihari S, Khanna KK (2015) Targeted Therapies for Triple-Negative Breast Cancer: Combating a Stubborn Disease. Trends in Pharmacological Sciences 36 (12):822-846. doi:10.1016/j.tips.2015.08.009 
2. Andreopoulou E, Schweber SJ, Sparano JA, McDaid HM (2015) Therapies for triple negative breast cancer. Expert Opinion on Pharmacotherapy 16 (7):983998. doi:10.1517/14656566.2015.1032246

3. Marmé F, Schneeweiss A (2015) Targeted Therapies in Triple-Negative Breast Cancer. Breast Care 10 (3):159-166. doi:10.1159/000433622

4. Fosu-Mensah N, Peris MS, Weeks HP, Cai J, Westwell AD (2015) Advances in small-molecule drug discovery for triple-negative breast cancer. Future Medicinal Chemistry 7 (15):2019-2039. doi:10.4155/fmc.15.129

5. Sagara A, Igarashi K, Otsuka M, Kodama A, Yamashita M, Sugiura R, Karasawa T, Arakawa K, Narita M, Kuzumaki N, Kato Y (2017) Endocan as a prognostic biomarker of triple-negative breast cancer. Breast Cancer Research and Treatment 161 (2):269-278. doi:10.1007/s10549-016-4057-8

6. Carmeliet P, Jain RK (2011) Molecular mechanisms and clinical applications of angiogenesis. Nature 473 (7347):298-307. doi:10.1038/nature10144

7. Gacche RN, Meshram RJ (2014) Angiogenic factors as potential drug target:

Efficacy and limitations of anti-angiogenic therapy. Biochimica et Biophysica Acta - Reviews on Cancer 1846 (1):161-179. doi:10.1016/j.bbcan.2014.05.002 8. Rydén L, Jirstrom K, Haglund M, Stal O, Fernö M (2010) Epidermal growth factor receptor and vascular endothelial growth factor receptor 2 are specific biomarkers in triple-negative breast cancer. Results from a controlled randomized trial with long-term follow-up. Breast Cancer Research and Treatment 120 (2):491-498. doi:10.1007/s10549-010-0758-6 9. Hillen F, Griffioen AW (2007) Tumour vascularization: Sprouting angiogenesis and beyond. Cancer and Metastasis Reviews 26 (3-4):489-502. doi:10.1007/s10555-007-9094-7

10. Ferrara N, Gerber HP, LeCouter J (2003) The biology of VEGF and its receptors. Nature Medicine 9 (6):669-676. doi:10.1038/nm0603-669

11. Bousquet G, El Bouchtaoui M, Sophie T, Leboeuf C, De Bazelaire C, Ratajczak P, Giacchetti S, De Roquancourt A, Bertheau P, Verneuil L, Feugeas JP, Espié M, Janin A (2017) Targeting autophagic cancer stem-cells to reverse chemoresistance in human triple negative breast cancer. Oncotarget 8 (21):35205-35221. doi:10.18632/oncotarget.16925

12. Falcon BL, Chintharlapalli S, Uhlik MT, Pytowski B (2016) Antagonist antibodies to vascular endothelial growth factor receptor 2 (VEGFR-2) as antiangiogenic agents. Pharmacology and Therapeutics 164:204-225.

doi:10.1016/j.pharmthera.2016.06.001

13. Ryter SW, Alam J, Choi AMK (2006) Heme oxygenase-1/carbon monoxide: From basic science to therapeutic applications. Physiological Reviews 86 (2):583650. doi:10.1152/physrev.00011.2005

14. Wu L, Wang R (2005) Carbon monoxide: Endogenous production, physiological functions, and pharmacological applications. Pharmacological Reviews 57 (4):585-630. doi:10.1124/pr.57.4.3

15. Johnson TR, Mann BE, Clark JE, Foresti R, Green CJ, Motterlini R (2003) Metal carbonyls: A new class of pharmaceuticals? Angewandte Chemie - International Edition 42 (32):3722-3729. doi:10.1002/anie.200301634 
16. Motterlini R, Mann BE, Foresti R (2005) Therapeutic applications of carbon monoxide-releasing molecules. Expert Opinion on Investigational Drugs 14 (11):1305-1318. doi:10.1517/13543784.14.11.1305

17. Motterlini R, Sawle P, Hammad J, Bains S, Alberto R, Foresti R, Green CJ (2005) CORM-A1: A new pharmacologically active carbon monoxide-releasing molecule. FASEB Journal 19 (2):284-286. doi:10.1096/fj.04-2169fje

18. Clark JE, Naughton P, Shurey S, Green CJ, Johnson TR, Mann BE, Foresti R, Motterlini R (2003) Cardioprotective actions by a water-soluble carbon monoxide-releasing molecule. Circulation research 93 (2):e2-8

19. Pitchumony TS, Spingler B, Motterlini R, Alberto R (2010) Syntheses, structural characterization and $\mathrm{CO}$ releasing properties of boranocarbonate [H3BCO2H]- derivatives. Organic and Biomolecular Chemistry 8 (21):4849-4854. doi:10.1039/c0ob00099j

20. Johnson TR, Mann BE, Teasdale IP, Adams H, Foresti R, Green CJ, Motterlini R (2007) Metal carbonyls as pharmaceuticals? [Ru(CO)3Cl(glycinate)], a COreleasing molecule with an extensive aqueous solution chemistry. Dalton Transactions (15):1500-1508. doi:10.1039/b613629j

21. Romanski S, Kraus B, Schatzschneider U, Neudörfl JM, Amslinger S, Schmalz HG (2011) Acyloxybutadiene iron tricarbonyl complexes as enzyme-triggered COreleasing molecules (ET-CORMs). Angewandte Chemie - International Edition 50 (10):2392-2396. doi:10.1002/anie.201006598

22. Niesel J, Pinto A, Peindy N'Dongo HW, Merz K, Ott I, Gust R, Schatzschneider $\mathrm{U}$ (2008) Photoinduced CO release, cellular uptake and cytotoxicity of a tris(pyrazolyl)methane (tpm) manganese tricarbonyl complex. Chemical Communications (15):1798-1800. doi:10.1039/b719075a

23. Jackson CS, Schmitt S, Dou QP, Kodanko JJ (2011) Synthesis, characterization, and reactivity of the stable iron carbonyl complex $[\mathrm{Fe}(\mathrm{CO})(\mathrm{N} 4 \mathrm{Py})](\mathrm{ClO} 4) 2$ :

Photoactivated carbon monoxide release, growth inhibitory activity, and peptide ligation. Inorganic Chemistry 50 (12):5336-5338. doi:10.1021/ic200676s

24. Kourti M, Jiang WG, Cai J (2017) Aspects of Carbon Monoxide in Form of COReleasing Molecules Used in Cancer Treatment: More Light on the Way. Oxidative Medicine and Cellular Longevity 2017:12. doi:10.1155/2017/9326454 25. Loboda A, Jozkowicz A, Dulak J (2015) HO-1/CO system in tumor growth, angiogenesis and metabolism - Targeting HO-1 as an anti-tumor therapy. Vascular Pharmacology 74:11-22. doi:10.1016/j.vph.2015.09.004 26. Romão CC, Vieira HLA (2015) Metal Carbonyl Prodrugs: CO Delivery and Beyond. In: Bioorganometallic Chemistry: Applications in Drug Discovery, Biocatalysis, and Imaging. pp 165-202. doi:10.1002/9783527673438.ch06 27. Kourti M, Westwell A, Jiang W, Cai J (2019) Repurposing old carbon monoxide-releasing molecules towards the anti-angiogenic therapy of triplenegative breast cancer. Oncotarget 10 (10):1132-1148

28. Ahmad S, Hewett PW, Fujisawa T, Sissaoui S, Cai M, Gueron G, Al-Ani B, Cudmore M, Faraz Ahmed S, Wong MKK, Wegiel B, Otterbein LE, Vítek L, Ramma W, Wang K, Ahmed A (2015) Carbon monoxide inhibits sprouting angiogenesis 
and vascular endothelial growth factor receptor- 2 phosphorylation. Thrombosis and Haemostasis 113 (2):329-337. doi:10.1160/TH14-01-0002

29. Van Meerloo J, Kaspers GJL, Cloos J (2011) Cell sensitivity assays: The MTT assay. Methods in Molecular Biology, vol 731. doi:10.1007/978-1-61779-80-5_20 30. Lopes-Bastos B, Jin L, Ruge F, Owen S, Sanders A, Cogle C, Chester J, Jiang WG, Cai J (2017) Association of breast carcinoma growth with a non-canonical axis of IFNY/IDO1/TSP1. Oncotarget 8 (49):85024-85039.

doi:10.18632/oncotarget.18781

31. Mohr F, Niesel J, Schatzschneider U, Lehmann CW (2012) Synthesis, structures, and $\mathrm{CO}$ releasing properties of two tricarbonyl manganese(I) complexes. Zeitschrift fur Anorganische und Allgemeine Chemie 638 (3-4):543546. doi:10.1002/zaac.201100422

32. Berlinguet L, Begin N, Babineau LM, Martel F, Vallee R, Laferte RO (1962) Biochemical studies of an unnatural and antitumor amino acid: 1aminocyclopentanecarboxylic acid. I. Toxicity and tissue distribution. Canadian journal of biochemistry and physiology 40:425-432

33. Connors TA, Elson LA, Haddow A, Ross WCJ (1960) The pharmacology and tumour growth inhibitory activity of 1-aminocyclopentane-1-carboxylic acid and related compounds. Biochemical Pharmacology 5 (1-2):108-129.

doi:10.1016/0006-2952(60)90014-9

34. Mykhailiuk PK, Starova V, Iurchenko V, Shishkina SV, Shishkin OV, Khilchevskyi O, Zaporozhets O (2013) 1-Amino-4,4-difluorocyclohexanecarboxylic acid as a promising building block for drug discovery: Design, synthesis and characterization. Tetrahedron 69 (20):4066-4075. doi:10.1016/j.tet.2013.03.072 35. Zhao Q, Xu T, Li M, Yang Y, Hu H, Wang S, Yan W, Chen R, Zhang C, Xu C (2015) Synthesis of six phenylalanine derivatives and their cell toxicity effect on human colon cancer cell line HT-29. Letters in Drug Design and Discovery 12 (6):466-470. doi:10.2174/1570180812666141206001604

36. Prütz WA (1986) Nitro-tyrosine as promoter of free radical damage in a DNA model system. Free Radical Research 2 (1-2):77-83.

doi:10.3109/10715768609088057

37. Simić A, Manojlović D, Šegan D, Todorović M (2007) Electrochemical behavior and antioxidant and prooxidant activity of natural phenolics. Molecules 12 (10):2327-2340. doi:10.3390/12102327

38. Wang P, Liu H, Zhao Q, Chen Y, Liu B, Zhang B, Zheng Q (2014) Syntheses and evaluation of drug-like properties of CO-releasing molecules containing ruthenium and group 6 metal. European Journal of Medicinal Chemistry 74:199215. doi:10.1016/j.ejmech.2013.12.041

39. Pliška V, Testa B, van de Waterbeemd H (2008) Lipophilicity in Drug Action and Toxicology, vol 4. Lipophilicity in Drug Action and Toxicology. doi:10.1002/9783527614998

40. Leeson PD, Springthorpe B (2007) The influence of drug-like concepts on decision-making in medicinal chemistry. Nature Reviews Drug Discovery 6 (11):881-890. doi:10.1038/nrd2445 
41. Franchini S, Manasieva LI, Sorbi C, Battisti UM, Fossa P, Cichero E, Denora N, lacobazzi RM, Cilia A, Pirona L, Ronsisvalle S, Arico G, Brasili L Synthesis, biological evaluation and molecular modeling of 1-oxa-4-thiaspiro- and 1,4dithiaspiro[4.5]decane derivatives as potent and selective 5-HT1A receptor agonists. (1768-3254 (Electronic))

42. Tonelli MA-O, Cichero E, Mahmoud AM, Rabbito A, Tasso B, Fossa P, Ligresti A Exploring the effectiveness of novel benzimidazoles as $C B 2$ ligands: synthesis, biological evaluation, molecular docking studies and ADMET prediction. (20402511 (Electronic))

43. Veber DF, Johnson SR, Cheng HY, Smith BR, Ward KW, Kopple KD (2002) Molecular properties that influence the oral bioavailability of drug candidates. Journal of Medicinal Chemistry 45 (12):2615-2623. doi:10.1021/jm020017n 44. Egorova KS, Ananikov VP (2017) Toxicity of Metal Compounds: Knowledge and Myths. Organometallics 36 (21):4071-4090.

doi:10.1021/acs.organomet.7b00605

45. Abhinand CS, Raju R, Soumya SJ, Arya PS, Sudhakaran PR (2016) VEGFA/VEGFR2 signaling network in endothelial cells relevant to angiogenesis. Journal of Cell Communication and Signaling 10 (4):347-354. doi:10.1007/s12079-0160352-8

46. Zhu X, Zhou W (2015) The emerging regulation of VEGFR-2 in triple-negative breast cancer. Frontiers in Endocrinology 6 (OCT). doi:10.3389/fendo.2015.00159 47. Potente $M$, Carmeliet $P$ (2017) The Link between Angiogenesis and Endothelial Metabolism. Annual Review of Physiology, vol 79.

doi:10.1146/annurev-physiol-021115-105134

48. Dulak J, Deshane J, Jozkowicz A, Agarwal A (2008) Heme oxygenase-1 and carbon monoxide in vascular pathobiology: Focus on angiogenesis. Circulation 117 (2):231-241. doi:10.1161/CIRCULATIONAHA.107.698316

49. Seixas JD, Chaves-Ferreira M, Montes-Grajales D, Gonçalves AM, Marques AR, Saraiva LM, Olivero-Verbel J, Romão CC, Bernardes GJL (2015) An N-Acetyl Cysteine Ruthenium Tricarbonyl Conjugate Enables Simultaneous Release of CO and Ablation of Reactive Oxygen Species. Chemistry - A European Journal 21 (42):14708-14712. doi:10.1002/chem.201502474

50. Kunz PC, Meyer H, Barthel J, Sollazzo S, Schmidt AM, Janiak C (2013) Metal carbonyls supported on iron oxide nanoparticles to trigger the $\mathrm{CO}-$ gasotransmitter release by magnetic heating. Chemical Communications 49 (43):4896-4898. doi:10.1039/c3cc41411f

51. Parasuraman S (2011) Toxicological screening. Journal of Pharmacology and Pharmacotherapeutics 2 (2):74-79. doi:10.4103/0976-500X.81895

52. Lai DY, Woo YT (2015) Amino and Nitro Compounds. In: Hamilton and Hardy's Industrial Toxicology: Sixth Edition. pp 615-642.

doi:10.1002/9781118834015.ch61

53. Li Volti G, Sacerdoti D, Sangras B, Vanella A, Mezentsev A, Scapagnini G, Falck JR, Abraham NG (2005) Carbon monoxide signaling in promoting angiogenesis in human microvessel endothelial cells. Antioxidants and Redox Signaling 7 (5-

6):704-710. doi:10.1089/ars.2005.7.704 
54. Jözkowicz A, Huk I, Nigisch A, Weigel G, Dietrich W, Motterlini R, Dulak J (2003) Heme oxygenase and angiogenic activity of endothelial cells: Stimulation by carbon monoxide and inhibition by tin protoporphyrin-IX. Antioxidants and Redox Signaling 5 (2):155-162

55. Choi YK, Kim CK, Lee H, Jeoung D, Ha KS, Kwon YG, Kim KW, Kim YM (2010) Carbon monoxide promotes VEGF expression by increasing HIF-1 $\alpha$ protein level via two distinct mechanisms, translational activation and stabilization of HIF-1 $\alpha$ protein. Journal of Biological Chemistry 285 (42):32116-32125.

doi:10.1074/jbc.M110.131284

56. Wilson JL, Bouillaud F, Almeida AS, Vieira HL, Ouidja MO, Dubois-Randé JL, Foresti R, Motterlini R (2017) Carbon monoxide reverses the metabolic adaptation of microglia cells to an inflammatory stimulus. Free Radical Biology and Medicine 104:311-323. doi:10.1016/j.freeradbiomed.2017.01.022

57. Menyhárt O, Harami-Papp H, Sukumar S, Schäfer R, Magnani L, de Barrios O, Győrffy B (2016) Guidelines for the selection of functional assays to evaluate the hallmarks of cancer. Biochimica et Biophysica Acta - Reviews on Cancer 1866 (2):300-319. doi:10.1016/j.bbcan.2016.10.002

58. Sass G, Leukel P, Schmitz V, Raskopf E, Ocker M, Neureiter D, Meissnitzer M, Tasika E, Tannapfel A, Tiegs $G$ (2008) Inhibition of heme oxygenase 1 expression by small interfering RNA decreases orthotopic tumor growth in livers of mice. International Journal of Cancer 123 (6):1269-1277. doi:10.1002/ijc.23695 59. Li Y, Su J, Dingzhang X, Zhang J, Yoshimoto M, Liu S, Bijian K, Gupta A, Squire JA, Alaoui Jamali MA, Bismar TA (2011) PTEN deletion and heme oxygenase-1 overexpression cooperate in prostate cancer progression and are associated with adverse clinical outcome. Journal of Pathology 224 (1):90-100.

doi:10.1002/path.2855

60. Szabo C (2016) Gasotransmitters in cancer: From pathophysiology to experimental therapy. Nature Reviews Drug Discovery 15 (3):185-203.

doi:10.1038/nrd.2015.1 